\title{
The chemical composition and manufacturing technology of glass beads excavated from the Hetian Bizili site, Xinjiang
}

\author{
Dong Wang ${ }^{1,2}$, Rui Wen ${ }^{1,2^{*}}$ (D) Julian Henderson ${ }^{3}$, Xingjun $\mathrm{Hu}^{4}$ and Wenying $\mathrm{Li}^{4}$
}

\begin{abstract}
The Hetian Bizili site in Lop County, located on the southern route of the Silk Road in Xinjiang, China, was a trade and cultural hub between the East and the West in ancient times. In 2016, a large number of glass beads were unearthed from the 40 tombs excavated on this site. In this study we determined the chemical compositions and manufacturing technology of bodies and decorations of twelve glass beads from the M5 tomb of Bizili by using LA-ICP-AES, EDXRF, Raman Spectrometry, and SR- $\mu \mathrm{CT}$. The chemical compositions of the beads were all $\mathrm{Na}_{2} \mathrm{O}-\mathrm{CaO}-\mathrm{SiO}_{2}$, with plant ash mainly used as a flux. Lead antimonate and lead stannate were used as the opacifying agents. We detected elevated levels of boron and high levels of phosphorus in some beads: this is discussed in the context of the type of flux used and the possible use of a P-rich opacifier. Some of the beads with high contents of aluminum may potentially come from Pakistan. In terms of manufacturing technology, the craftsmen made 'eye' beads in different ways and also trail decorated beads.
\end{abstract}

Keywords: Glass eye beads, Xinjiang, The silk road, Bizili site

\section{Introduction}

The Xinjiang Uygur Autonomous Region, located in the northwest of China (Fig. 1), has been a vital area of cultural diversity and complexity [1]. Previously, archaeologists mainly focused on the Central Plains of China. Nowadays, Xinjiang has attracted more attention because the findings there can indicate the interactions among various populations as reflected in traded objects, technologies, and cultures [2]. A significant number of glass beads in various styles (including faience) have been excavated in the Xinjiang area during the past decades. Based on the published archaeological reports, the earliest faience in China, as early as 1900-1500 BC, was found at the Adunqiaolu site of Wenquan County, Xinjiang [3]. Moreover, a great number of faience beads have been unearthed at Tianshanbeilu (1500-1400 BC) and Ya'er

\footnotetext{
*Correspondence: rwen80@163.com

${ }^{1}$ Key Laboratory for Cultural Heritage Study \& Conservation (Northwest University), Ministry of Education, Xi'an 710069, PR China

Full list of author information is available at the end of the article
}

(1050-910 BC) in Hami $[4,5]$. The earliest glass beads in China were found in Baicheng County and Tacheng County, Xinjiang, dating back to $1100-500$ BC. They are all soda-lime glasses, believed to originate from the West. However, some of them have differences in their chemical compositions, which may conceivably be attributable to the use of local raw materials to make them [6]. Many glass beads spread to China carried by ancient nomadic people and all these sites are located in the north of Xinjiang far away from the Silk Road, indicating that cultural exchanges between the East and the West had started before the establishment of the Silk Road- or they may represent evidence for an early Silk Road. In comparison to the south of Xinjiang, the evidence of glass beads in this period is rare until the Han dynasty, when the evidence for them increased sharply. A large number of glass beads has been found in southern Xinjiang at Shanpula [7], Niya [8, 9], Jierzankale [10] and Zhagunluke [11], with more than a thousand glass beads deriving from the former two sites which is more than is currently known from the area to the south of the Silk Road.
Springer Open

(c) The Author(s) 2020. This article is licensed under a Creative Commons Attribution 4.0 International License, which permits use, sharing adaptation, distribution and reproduction in any medium or format, as long as you give appropriate credit to the original author(s) and the source, provide a link to the Creative Commons licence, and indicate if changes were made. The images or other third party material in this article are included in the article's Creative Commons licence, unless indicated otherwise in a credit line to the material. If material is not included in the article's Creative Commons licence and your intended use is not permitted by statutory regulation or exceeds the permitted use, you will need to obtain permission directly from the copyright holder. To view a copy of this licence, visit http://creativeco mmons.org/licenses/by/4.0/. The Creative Commons Public Domain Dedication waiver (http://creativecommons.org/publicdomain/ zero/1.0/) applies to the data made available in this article, unless otherwise stated in a credit line to the data. 
Meanwhile, the number of glass beads in Northern Xinjiang is relatively small. Such a phenomenon may be linked to the influence of Zhang Qian in the Han dynasty. The Han government promoted trade and cultural exchanges between the Central Plains and Western regions. Also, those who travelled along the Silk Road including traders preferred the southern route because of safety concerns: the northeast of Xinjiang was occupied by the Huns.

The Bizili site is situated to the southeast of the Bizili Village, Lop County, in Southern Xinjiang (Fig. 1). The Xinjiang Institute of Cultural Relics and Archaeology excavated 40 tombs in cooperation with those constructing a road in 2016. According to the characteristics of these tombs, Bizili dates from the Han Dynasty (202 BC-220 AD) to the Wei and Jin Dynasties (220-420 AD). These tombs are all pit tombs and can be divided into convex-shaped pit tombs and rectangular pit tombs. M5 is the largest convex-shaped pit tomb and contains many bodies: ninety-seven human bones were found, with more females represented than males. Eleven more human bones were at the bottom of the tomb. Although the tomb was looted and burned sometime before it was excavated, a lot of finds were still preserved, such as pottery, woodwork, pieces of iron, woolen fabrics, and beads. Notably, the first mutton-fat jade pendant to have been found in Xinjiang was discovered. The dry climate helped to preserve historic relics there [12].

In the Han dynasty (202 BC-220 AD), Bizili belonged to Khotan, a kingdom to the south of the Silk Road. This paper aims to investigate the technology used to make glass beads found there by using chemical analysis and to consider where the glass and the beads were made. It was hoped that this would provide useful evidence for the interaction, distribution, trade and exchange of glass beads along the terrestrial Silk Road as reflected in the beads found in the Bizili burials. We report some of the first trace element analysis of Chinese glasses.

\section{Materials and methods}

In this study, twelve glass beads excavated from tomb M5 at Bizili dating to the Western Han dynasty (202 BC-8 AD) were selected and chemically analysed. Table 1 provides a description of the samples, including the sizes and bead types. They all date to the Western Han Dynasty (202 BC to $8 \mathrm{AD}$ ). The majority of the samples were glass eye beads, a special type with an eye motif

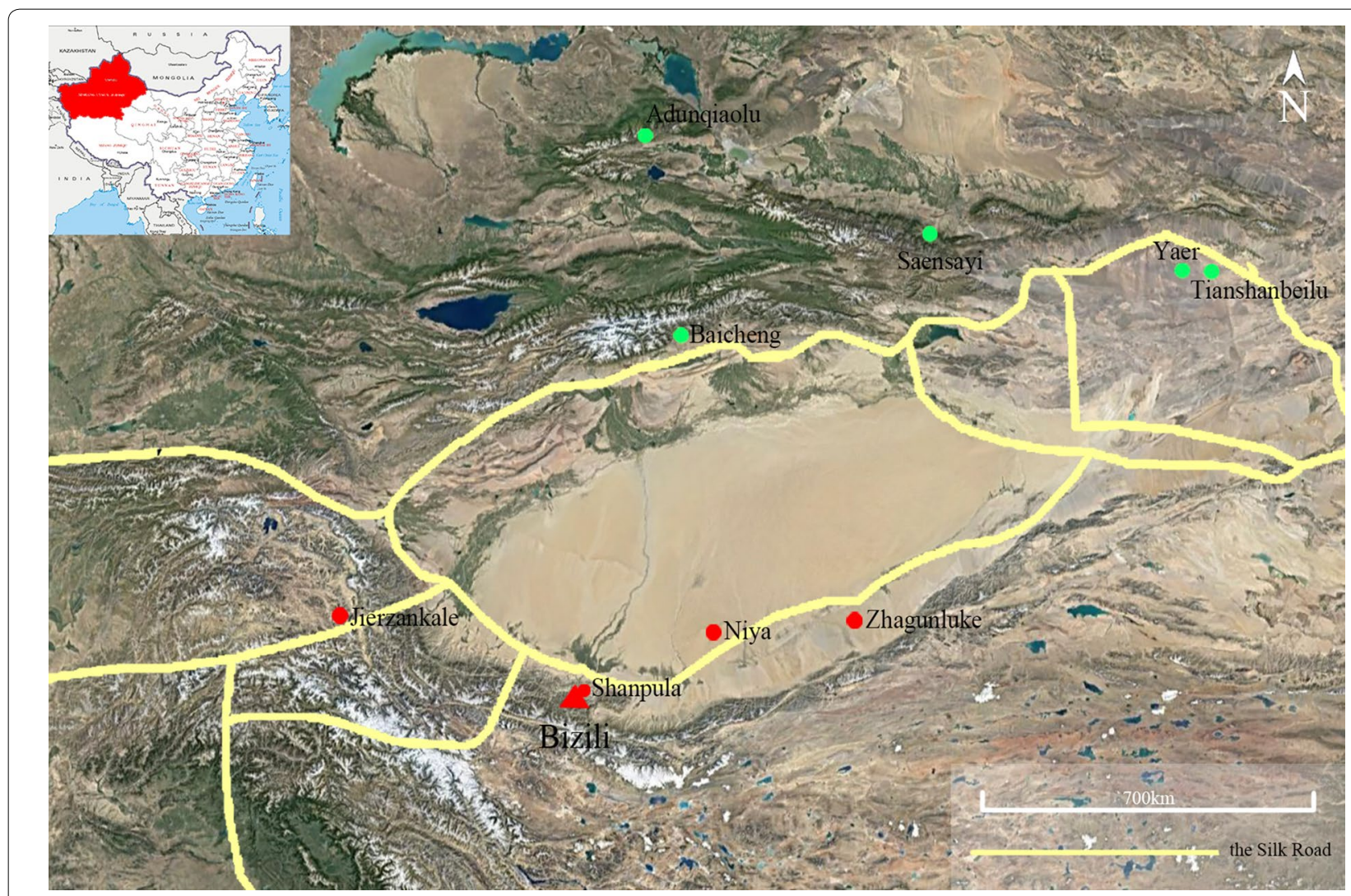

Fig. 1 Map of Xinjiang showing the main sites discussed in the text. The location of Bizili is shown. The other sites that date to before $500 \mathrm{BC}$ are plotted with a green symbol and those that date to after 500 BC are plotted with a red symbol 
Table 1 Details of the glass beads from the Bizili site

\begin{tabular}{lll}
\hline Sample & Size & Type \\
\hline HLB-1 & $\begin{array}{l}\text { Diameter: } 1 \mathrm{~cm} \\
\text { Aperture: } 0.3-0.5 \mathrm{~cm}\end{array}$ & Glass eye bead \\
HLB-2 & $\begin{array}{l}\text { Diameter: } 1.1 \mathrm{~cm} \\
\text { Aperture: } 0.4 \mathrm{~cm}\end{array}$ & Glass eye bead \\
& $\begin{array}{l}\text { Diameter: } 1.3 \mathrm{~cm} \\
\text { HLB-3 }\end{array}$ & Glass eye bead \\
HLB-4 & Diameter: $0.5 \mathrm{~cm}$ & Glass eye bead \\
HLB-5 & Aperture: $0.3 \mathrm{~cm}$ & Glass eye bead \\
HLB-6 & & Glass eye bead \\
HLB-7 & & Monochrome bead \\
HLB-8 & Diameter: $0.6 \mathrm{~cm}$ & Glass eye bead \\
HLB-9 & Aperture: $0.2 \mathrm{~cm}$ & Glass eye bead \\
HLB-10 & & Decorated glass bead \\
HLB-11 & Diameter: $0.35 \mathrm{~cm}$ & Monochrome bead \\
HLB-12 & Aperture: $0.2 \mathrm{~cm}$ & \\
& Diameter: $1.4 \mathrm{~cm}$ & Glass bead with pigment \\
\hline
\end{tabular}

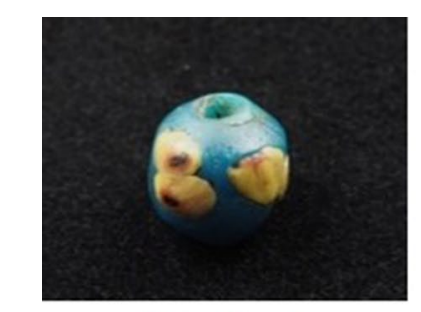

HLB-1

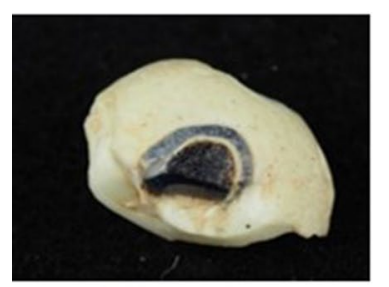

HLB-5

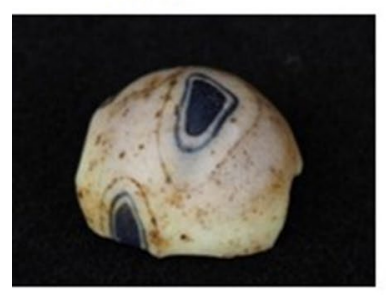

HLB-9

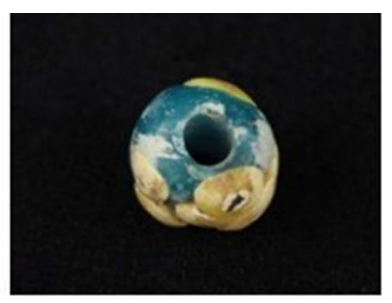

HLB-2

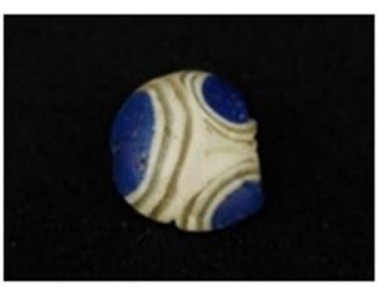

HLB-6

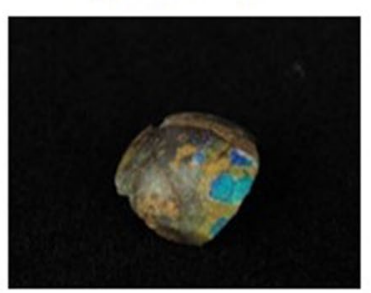

HLB-10
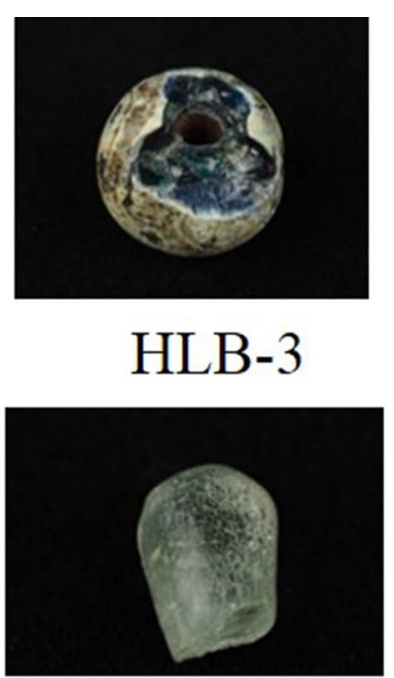

HLB-7

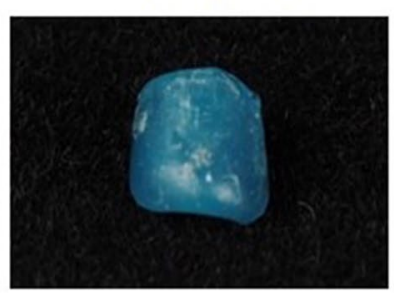

HLB-11

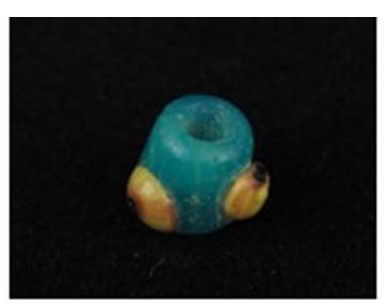

HLB-4

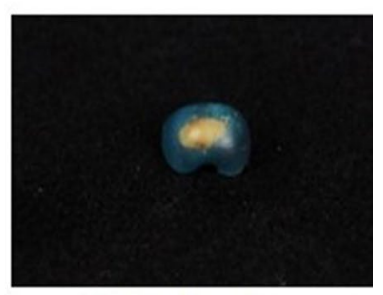

HLB-8

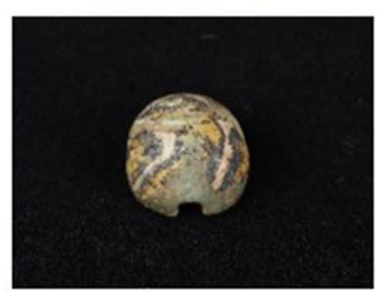

HLB-12

Fig. 2 The glass beads from Bizili, Xinjiang 
between the detector and samples is $10 \mathrm{~cm}$ with the source energy of $28 \mathrm{keV}$.

Chemical compositions of the samples were determined using energy dispersion X-ray fluorescence spectrometry (ED-XRF) and laser ablation inductivelycoupled plasma atomic emission spectroscopy (LAICP-AES). For the better preserved monochrome beads without complex ornaments, the bulk chemistry was determined using ED-XRF at the School of Cultural Heritage, Northwest University. The instrument used was a BRUKER ARTAX 400, fitted with a Mo anode. The primary X-ray beam used was $1 \mathrm{~mm}$ in diameter. The X-ray energy used was $30 \mathrm{kV}$, the current was $900 \mu \mathrm{A}$, and the counting time was $300 \mathrm{~s}$. During analysis, a helium purge was used to allow for the detection of light elements such as $\mathrm{Na}_{2} \mathrm{O}$ and $\mathrm{MgO}$. The standards used for calibration were Corning Glasses B, C and D. Table 2 shows the normalized major elemental contents of the glass standards compared with expected results. A total of 24 analyses are reported here (Table 4).

The beads decorated with complex patterns (HLB-1, HLB-2, HLB-3, HLB-4, HLB-5, HLB-6, HLB-8, HLB-9, HLB-10 and HLB-12) were analyzed using LA-ICP-AES to obtain quantitative chemical compositions of different parts of the glass beads. The analyes were performed in the School of Archaeology and Museology, Peking University. The LA-ICP-AES is equipped with a Nd-YAG laser and an RF generator of $40.82 \mathrm{MHz}$ and $1.1 \mathrm{kw}$. The Q-switched laser mode was used with a laser wavelength of $266 \mathrm{~nm}$ and output energy of $10 \pm 1 \mathrm{~mJ}$. The auxiliary gas pressure and nebulizer gas pressure were $0 \mathrm{psi}$ and 30 psi, respectively. The Argon flow rate in the Plasma was $1.4 \mathrm{~L} / \mathrm{min}$. Helium was used as the carrier gas with a flow rate of $800 \mathrm{~mL} / \mathrm{min}$. Silica was used as an internal standard for minor and trace element analysis of the glass using this LA-ICP system. For major element analysis, external standards were used for calibration due to the different silica contents in samples and standards. The glass standards were Corning B and D from the Corning Museum of Glass. Table 3 shows the normalized major element contents of the glass standards.

Raman spectroscopy is a non-destructive method for analyzing the structure and the chemical bonds within the material by obtaining the characteristic wavelength frequencies of samples without special sample preparation. It was performed at the Emperor Qin Shihuang's Mausoleum Site Museum (Xi'an, Shaanxi) at room temperature, using a $514 \mathrm{~nm} \mathrm{Nd:YAG} \mathrm{laser} \mathrm{for} \mathrm{the} \mathrm{spectral}$ range from 100 to $1000 \mathrm{~cm}^{-1}$. A laser power of $10 \mathrm{~mW}$ was employed, and the acquisition time was $10 \mathrm{~s}$ for each integration which were accumulated 3 times. The attribution of the Raman signatures of crystalline phases was made by comparing them with data presented in the literature.

\section{Results}

\section{Chemical composition}

The chemical analyses of different glass colours for the 12 beads are given in Table 4 , a total of 24 analyses. The very low levels especially of $\mathrm{Na}_{2} \mathrm{O}$ are produced by weathering:

Table 2 Normalized major element contents of the glass standards (ED-XRF) (wt\%)

\begin{tabular}{|c|c|c|c|c|c|c|c|c|c|}
\hline & $\mathrm{Na}_{2} \mathrm{O}$ & $\mathrm{MgO}$ & $\mathrm{Al}_{2} \mathrm{O}_{3}$ & $\mathrm{SiO}_{2}$ & $\mathrm{P}_{2} \mathrm{O}_{5}$ & $\mathrm{~K}_{2} \mathrm{O}$ & $\mathrm{CaO}$ & $\mathrm{Fe}_{2} \mathrm{O}_{3}$ & $\mathrm{PbO}$ \\
\hline \multicolumn{10}{|l|}{ Corning B } \\
\hline Average & 15.8 & 1.1 & 4.6 & 62.8 & 0.8 & 1.0 & 8.7 & 0.4 & 0.6 \\
\hline $\mathrm{RSD} \%$ & 14.0 & 63.0 & 10.0 & 1.0 & 8.0 & 4.0 & 2.0 & 7.0 & 4.0 \\
\hline Reference composition wt\% & 17.00 & 1.03 & 4.36 & 61.60 & 0.82 & 1.00 & 8.56 & 0.34 & 0.61 \\
\hline Absolute error wt\% & -1.20 & 0.07 & 0.24 & 1.20 & -0.02 & 0.00 & 0.14 & 0.06 & -0.01 \\
\hline Relative error \% & 7.06 & 6.80 & 5.50 & 1.95 & 2.44 & 0.00 & 1.64 & 17.65 & 1.64 \\
\hline \multicolumn{10}{|l|}{ Corning $C$} \\
\hline Average & 1.6 & 2.5 & 0.7 & 35.7 & 0.1 & 2.6 & 4.8 & 0.3 & 35.3 \\
\hline RSD \% & 58.0 & 60.0 & 50.0 & 4.0 & 19.0 & 15.0 & 10.0 & 14.0 & 6.0 \\
\hline Reference composition wt\% & 1.07 & 2.76 & 0.87 & 34.90 & 0.14 & 2.84 & 5.07 & 0.34 & 36.70 \\
\hline Absolute error wt\% & 0.49 & -0.29 & -0.13 & 0.81 & 0.01 & -0.21 & -0.28 & -0.03 & -1.39 \\
\hline Relative error \% & 45.36 & 10.69 & 14.90 & 2.33 & 4.29 & 7.51 & 5.61 & 7.55 & 3.79 \\
\hline \multicolumn{10}{|l|}{ Corning D } \\
\hline Average & 1.2 & 4.8 & 5.0 & 54.6 & 5.9 & 12.6 & 13.6 & 0.4 & 0.4 \\
\hline $\mathrm{RSD} \%$ & 91.8 & 11.2 & 2.8 & 1.8 & 3.5 & 1.6 & 1.1 & 1.5 & 1.3 \\
\hline Reference composition wt\% & 1.20 & 3.94 & 5.31 & 55.24 & 3.93 & 11.30 & 14.80 & 0.52 & 0.48 \\
\hline Absolute error wt\% & 0.0 & 0.9 & -0.3 & -0.6 & 2.0 & 1.3 & -1.2 & -0.1 & -0.1 \\
\hline Relative error \% & 0.00 & 21.83 & 5.84 & 1.16 & 50.13 & 11.50 & 8.11 & 23.08 & 16.67 \\
\hline
\end{tabular}


Table 3 Normalized major element contents of the glass standards (LA-ICP-AES) (wt\%)

\begin{tabular}{|c|c|c|c|c|c|c|c|c|}
\hline & $\mathrm{Na}_{2} \mathrm{O}$ & $\mathrm{MgO}$ & $\mathrm{Al}_{2} \mathrm{O}_{3}$ & $\mathrm{SiO}_{2}$ & $\mathrm{P}_{2} \mathrm{O}_{5}$ & $\mathrm{~K}_{2} \mathrm{O}$ & $\mathrm{CaO}$ & $\mathrm{Fe}_{2} \mathrm{O}_{3}$ \\
\hline \multicolumn{9}{|l|}{ Corning-d } \\
\hline Average & 1.38 & 3.99 & 5.73 & 53.98 & 4.05 & 12.41 & 15.24 & 0.55 \\
\hline RSD \% & 1.56 & 0.78 & 1.33 & 0.28 & 2.80 & 1.95 & 1.03 & 1.96 \\
\hline Reference composition wt\% & 1.20 & 3.94 & 5.31 & 55.24 & 3.93 & 11.30 & 14.80 & 0.52 \\
\hline Absolute error wt $\%$ & 0.18 & 0.05 & 0.42 & -1.26 & 0.12 & 1.11 & 0.43 & 0.03 \\
\hline Relative error \% & 14.92 & 1.17 & 7.82 & 2.28 & 3.00 & 9.78 & 2.94 & 5.96 \\
\hline \multicolumn{9}{|l|}{ Corning-b } \\
\hline Average & 16.14 & 1.06 & 4.61 & 62.68 & 0.90 & 0.95 & 9.01 & 0.39 \\
\hline RSD \% & 0.24 & 0.05 & 0.57 & 0.13 & 1.16 & 2.28 & 0.74 & 1.76 \\
\hline Reference composition wt $\%$ & 17.00 & 1.03 & 4.36 & 61.60 & 0.82 & 1.00 & 8.56 & 0.34 \\
\hline Absolute error wt $\%$ & -0.86 & 0.03 & 0.25 & 1.08 & 0.08 & -0.06 & 0.45 & 0.05 \\
\hline Relative error \% & 5.04 & 2.91 & 5.62 & 1.75 & 9.88 & 5.50 & 5.22 & 14.41 \\
\hline
\end{tabular}

glass in the tomb can be weathered in variable ways, depending on microenvironments in the burial. In addition, the use of additives can lead to low $\mathrm{Na}_{2} \mathrm{O}$ contents in glasses. The primary raw materials of glass are sands and fluxes often incorporating lime. Moreover, there will be deliberately added materials, such as chromophores and opacfiers and elements associated with them. These compounds would lead to a relatively low content of other components in glass. In this study, some samples (HLB6 white, HLB9 white, HLB10 green, HLB12 black, HLB12 white, HLB1yellow, HLB2yellow, HLB4yellow, HLB8yellow and HLB5white) have opacifiers. According to the research by Brill, we removed the additives, and recalculated the remaining oxides to bring their sum to $100 \%$. The recalculated results show that the $\mathrm{Na}_{2} \mathrm{O}$ levels increase $[15,16]$.

The rarity and fragility of cultural relics, such as glass beads, requires the use of non-destructive or minimally invasive analysis techniques. In our study, we used LAICP-AES to obtain the chemical compositions through multiple tests at different depths. Where possible, we chosen the best data for unweathered glass.

Based on their chemical compositions, all the glass beads from the Bizili site are of a soda-lime-silica composition but with variations in the relative concentrations of the alkaline fluxes present and lead oxide in coloured decoration. Soda concentrations in unweathered glasses range from 5.75 to $12.91 \%$. Some glasses contain high potassium oxide levels of upto $7.1 \%$, levels approximately equal to that of soda which can therefore be classified as mixed alkali glasses. Additionally, melting temperatures of opaque yellow glasses would have been reduced by the presence of upto $20 \% \mathrm{PbO}$.

Henderson and Warren [17], Shortland [18] and Duckworth et al. [19] noted that there is often an excess of lead present in such opacified glasses to account for the amount needed to form lead-rich opacifying crystals, the excess lead being present in the glass matrix and therefore reducing the overall melting temperature of the glass [17-19].

The levels of calcium oxide in unweathered glasses varies from quite low (2.13\%) to very high (15.99\%). Beads HLB-1 blue, HLB2-blue and HLB10-green contain very high $\mathrm{Al}_{2} \mathrm{O}_{3}$ levels at 9.34\%, 8.12\% and $6.77 \%$ respectively. Very high $\mathrm{P}_{2} \mathrm{O}_{5}$ levels in four of the HBL-12 colours are unusual; the high levels in HLB2 and 9 should also be noted and will be discussed further below. Four of the opaque yellow components of the glass eye beads with turquoise blue bodies (HLB-1, HLB-2, HLB-4, and HLB-8) are similar in chemical compositions, except for some variation in the concentrations of $\mathrm{SnO}_{2}$ and $\mathrm{PbO}$ in opaque yellow glasses. High antimony in white glasses is associated with a calcium antimonate opacifer (see below). Three out of four opaque white glasses (HLB5, HLB6 and HLB9) also contain PbO at between 5.4 and $7.11 \%$ so this would be dissolved in the glass matrices.

The similarity in chemical composition of these four beads includes some characteristics of the colorants: three contain between $0.61 \% \mathrm{CuO}$ and $0.67 \% \mathrm{CuO}$; HLB1 contains $0.82 \% \mathrm{CuO}$. HLB1 and HLB2 contain 0.8 and $0.18 \% \mathrm{ZnO}$. This could indicate that scrap brass was used to colour them. However HLB1 and HLB2 also contain $0.44 \% \mathrm{SnO}_{2}$. Other turquoise beads are also coloured by CuO: HBL3, HBL9 appearing 'black' and HBL11; HBL8 contains $0.67 \% \mathrm{CuO}$ but is weathered.

Two translucent glasses contain sufficient levels of $\mathrm{CoO}$ to colour them blue: the decoration of HLB5 appearing 'black' and the body of HLB6 but both are highly weathered. They are both further characterised by $\mathrm{NiO}$ and $\mathrm{ZnO}$ which it can tentatively be suggested are associated 
Table 4 Major, minor and trace element oxide compositions of the glass beads (wt\% oxide)

\begin{tabular}{|c|c|c|c|c|c|c|c|c|c|c|c|c|c|c|}
\hline Sample ID & $\mathrm{SiO}_{2}$ & $\mathrm{Al}_{2} \mathrm{O}_{3}$ & $\mathrm{Fe}_{2} \mathrm{O}_{3}$ & $\mathrm{MgO}$ & $\mathrm{CaO}$ & $\mathrm{Na}_{2} \mathrm{O}$ & $\mathrm{K}_{2} \mathrm{O}$ & $\mathrm{Na}_{2} \mathrm{O}+\mathrm{K}_{2} \mathrm{O}$ & $\mathrm{MnO}$ & $\mathrm{P}_{2} \mathrm{O}_{5}$ & $\mathrm{TiO}_{2}$ & $\mathrm{Sb}_{2} \mathrm{O}_{3}$ & Method & Weathering degree \\
\hline HLB1-blue & 46.14 & 9.34 & 3.20 & 2.34 & 15.99 & 7.76 & 6.50 & 14.26 & 0.29 & 4.16 & 0.61 & 0.15 & LA-ICP-AES & Unweathered \\
\hline HLB1-yellow & 63.96 & 6.69 & 0.86 & 3.57 & 5.11 & 3.79 & 5.44 & 9.23 & 0.07 & 0.64 & 0.26 & 0.06 & LA-ICP-AES & Weathered \\
\hline HLB2-blue & 66.40 & 8.12 & 1.86 & 2.65 & 6.27 & 3.76 & 4.97 & 8.73 & 0.15 & 2.93 & 0.52 & 0.06 & LA-ICP-AES & Weathered \\
\hline HLB2-yellow & 52.33 & 4.89 & 1.03 & 1.69 & 4.23 & 2.48 & 3.36 & 5.84 & 0.05 & 2.85 & 0.28 & 0.07 & LA-ICP-AES & Weathered \\
\hline HLB3- blue & 67.44 & 4.37 & 0.57 & 3.32 & 3.43 & 12.55 & 6.20 & 18.75 & 0.08 & 0.49 & 0.16 & 0.01 & LA-ICP-AES & Unweathered \\
\hline HLB3-white1 & 72.54 & 4.81 & 1.77 & 2.39 & 7.51 & 2.29 & 5.30 & 7.59 & 0.32 & 0.29 & 0.36 & 1.35 & LA-ICP-AES & Weathered \\
\hline HLB4-blue & 75.74 & 3.08 & 0.44 & 2.29 & 2.13 & 9.82 & 5.18 & 15 & 0.05 & 0.25 & 0.11 & 0.00 & LA-ICP-AES & Unweathered \\
\hline HLB4-yellow & 66.89 & 4.82 & 0.50 & 3.05 & 3.43 & 8.57 & 7.11 & 15.68 & 0.14 & 0.40 & 0.18 & 0.01 & LA-ICP-AES & Unweathered \\
\hline HLB5-black & 87.32 & 3.03 & 1.69 & 0.56 & 1.85 & 1.00 & 1.84 & 2.84 & 1.25 & 0.29 & 0.22 & 0.05 & LA-ICP-AES & Highly weathered \\
\hline HLB5-white & 72.55 & 2.40 & 0.53 & 0.50 & 1.52 & 2.88 & 2.17 & 5.05 & 0.19 & 0.41 & 0.18 & 8.49 & LA-ICP-AES & Weathered \\
\hline HLB6-blue & 87.32 & 2.65 & 1.03 & 0.76 & 2.54 & 1.75 & 1.98 & 3.73 & 0.36 & 0.34 & 0.24 & 0.09 & LA-ICP-AES & Highly weathered \\
\hline HLB6-white & 70.20 & 2.40 & 0.48 & 0.74 & 2.55 & 5.75 & 2.75 & 8.5 & 0.76 & 0.35 & 0.14 & 8.15 & LA-ICP-AES & Unweathered \\
\hline HLB7 & 91.72 & 1.27 & 0.74 & 0.88 & 2.70 & 0.16 & 1.45 & 1.61 & 0.07 & ND & 0.10 & 0.05 & ED-XRF & Highly weathered \\
\hline HLB8-yellow & 67.60 & 4.60 & 1.06 & 2.52 & 2.83 & 8.64 & 5.95 & 14.59 & 0.13 & 0.36 & 0.19 & 0.00 & LA-ICP-AES & Unweathered \\
\hline HLB8-blue & 83.84 & 6.69 & 0.48 & 1.70 & 1.84 & 1.00 & 2.71 & 3.71 & 0.09 & 0.29 & 0.21 & 0.01 & LA-ICP-AES & Highly weathered \\
\hline HLB9-black & 72.34 & 6.86 & 0.74 & 0.42 & 2.15 & 3.05 & 5.45 & 8.5 & 0.22 & 2.93 & 0.69 & 0.59 & LA-ICP-AES & Weathered \\
\hline HLB9-white1 & 74.27 & 2.55 & 0.37 & 0.55 & 3.57 & 5.94 & 2.30 & 8.24 & 0.73 & 0.26 & 0.12 & 3.40 & LA-ICP-AES & Unweathered \\
\hline HLB10-green & 68.17 & 6.77 & 2.36 & 3.42 & 7.02 & 5.49 & 4.62 & 10.11 & 0.68 & 0.26 & 0.24 & 0.00 & LA-ICP-AES & Unweathered \\
\hline HLB-11-green & 81.24 & 4.31 & 1.30 & 1.71 & 4.23 & 0.49 & 2.80 & 3.29 & 0.22 & 0.02 & 0.27 & 0.28 & ED-XRF & Highly weathered \\
\hline HLB12-blue & 66.32 & 4.99 & 0.48 & 4.06 & 3.38 & 12.91 & 6.05 & 18.96 & 0.08 & 0.39 & 0.16 & 0.00 & LA-ICP-AES & Unweathered \\
\hline HLB12-black & 14.62 & 1.74 & 1.24 & 3.69 & 6.66 & 3.06 & 2.23 & 5.29 & 44.77 & 8.48 & 0.23 & 2.63 & LA-ICP-AES & unweathered \\
\hline HLB12-pink & 54.56 & 4.16 & 2.97 & 12.11 & 5.54 & 2.08 & 5.22 & 7.3 & 0.40 & 8.02 & 0.48 & 0.08 & LA-ICP-AES & unweathered \\
\hline HLB12-white1 & 44.02 & 3.01 & 1.87 & 2.43 & 6.40 & 2.64 & 2.69 & 5.33 & 5.38 & 7.69 & 0.27 & 1.55 & LA-ICP-AES & unweathered \\
\hline HLB12-white2 & 20.50 & 2.11 & 1.41 & 2.97 & 10.20 & 2.40 & 2.71 & 5.11 & 9.26 & 17.18 & 0.52 & 1.73 & LA-ICP-AES & Unweathered \\
\hline Sample ID & $\mathrm{CuO}$ & $\mathrm{PbO}$ & $\mathrm{CoO}$ & $\mathrm{BaO}$ & $\mathrm{SnO}_{2}$ & SrO & $\mathrm{ZnO}$ & $\mathrm{B}_{2} \mathrm{O}_{3}$ & $\mathrm{~V}_{2} \mathrm{O}_{5}$ & $\mathrm{NiO}$ & ZrO & $\mathrm{Ag}_{2} \mathrm{O}$ & Method & \\
\hline HLB1-blue & 0.82 & 0.23 & 0.02 & 0.16 & 0.44 & 0.09 & 0.80 & 0.20 & 0.38 & 0.37 & 0.00 & 0.01 & LA-ICP-AES & Unweathered \\
\hline HLB1-yellow & 0.08 & 7.02 & 0.00 & 0.15 & 1.86 & 0.05 & 0.15 & 0.09 & 0.07 & 0.06 & 0.01 & 0.00 & LA-ICP-AES & Weathered \\
\hline HLB2-blue & 0.63 & 0.14 & 0.01 & 0.24 & 0.46 & 0.05 & 0.18 & 0.09 & 0.32 & 0.19 & 0.00 & 0.00 & LA-ICP-AES & Weathered \\
\hline HLB2-yellow & 0.43 & 20.03 & 0.00 & 0.41 & 5.43 & 0.08 & 0.10 & 0.06 & 0.10 & 0.07 & 0.00 & 0.03 & LA-ICP-AES & Weathered \\
\hline HLB3-blue & 1.03 & 0.00 & 0.00 & 0.09 & 0.04 & 0.05 & 0.01 & 0.10 & 0.02 & 0.04 & 0.00 & 0.00 & LA-ICP-AES & Unweathered \\
\hline HLB3-white1 & 0.26 & 0.21 & 0.05 & 0.21 & 0.07 & 0.02 & 0.08 & 0.10 & 0.02 & 0.04 & 0.01 & 0.01 & LA-ICP-AES & Weathered \\
\hline HLB4-blue & 0.61 & 0.00 & 0.00 & 0.14 & 0.02 & 0.03 & 0.00 & 0.05 & 0.01 & 0.02 & 0.00 & 0.00 & LA-ICP-AES & Unweathered \\
\hline HLB4-yellow & 0.01 & 4.17 & 0.00 & 0.11 & 0.46 & 0.04 & 0.00 & 0.06 & 0.01 & 0.02 & 0.01 & 0.00 & LA-ICP-AES & Unweathered \\
\hline HLB5-black & 0.16 & 0.00 & 0.09 & 0.13 & 0.11 & 0.03 & 0.07 & 0.14 & 0.05 & 0.11 & 0.00 & 0.00 & LA-ICP-AES & Highly weathered \\
\hline HLB5-white & 0.08 & 7.11 & 0.00 & 0.01 & 0.40 & 0.01 & 0.12 & 0.21 & 0.08 & 0.16 & 0.00 & 0.00 & LA-ICP-AES & Weathered \\
\hline HLB6-blue & 0.15 & 0.06 & 0.08 & 0.03 & 0.13 & 0.02 & 0.15 & 0.15 & 0.05 & 0.11 & 0.00 & 0.01 & LA-ICP-AES & Highly weathered \\
\hline HLB6-white & 0.06 & 5.40 & 0.00 & 0.02 & 0.08 & 0.02 & 0.06 & 0.07 & 0.01 & 0.02 & 0.00 & 0.00 & LA-ICP-AES & Unweathered \\
\hline HLB-7 & 0.01 & 0.07 & 0.01 & 0.69 & 0.05 & 0.02 & 0.01 & ND & ND & ND & ND & ND & ED-XRF & Highly weathered \\
\hline HLB8-yellow & 0.09 & 5.00 & 0.00 & 0.11 & 0.76 & 0.03 & 0.01 & 0.07 & 0.01 & 0.03 & 0.01 & 0.00 & LA-ICP-AES & Unweathered \\
\hline HLB8-blue & 0.67 & 0.03 & 0.00 & 0.11 & 0.09 & 0.02 & 0.01 & 0.11 & 0.04 & 0.07 & 0.00 & 0.00 & LA-ICP-AES & Highly weathered \\
\hline HLB9-black & 0.94 & 0.09 & 0.00 & 0.03 & 0.97 & 0.02 & 0.72 & 0.73 & 0.36 & 0.68 & 0.00 & 0.00 & LA-ICP-AES & Weathered \\
\hline HLB9-white1 & 0.04 & 5.60 & 0.00 & 0.03 & 0.06 & 0.03 & 0.06 & 0.07 & 0.01 & 0.02 & 0.00 & 0.01 & LA-ICP-AES & Unweathered \\
\hline HLB10-green & 0.09 & 0.00 & 0.00 & 0.16 & 0.19 & 0.05 & 0.02 & 0.11 & 0.19 & 0.16 & 0.00 & 0.01 & LA-ICP-AES & Unweathered \\
\hline HLB-11-green & 2.11 & 0.02 & 0.01 & 0.76 & 0.13 & 0.10 & 0.02 & ND & ND & ND & ND & ND & ED-XRF & Highly weathered \\
\hline HLB12-blue & 0.88 & 0.00 & 0.00 & 0.08 & 0.02 & 0.06 & 0.00 & 0.08 & 0.01 & 0.02 & 0.01 & 0.00 & LA-ICP-AES & Unweathered \\
\hline HLB12-black & 0.27 & 9.72 & 0.07 & 0.07 & 0.04 & 0.07 & 0.27 & 0.07 & 0.03 & 0.04 & 0.00 & 0.00 & LA-ICP-AES & Unweathered \\
\hline HLB12-pink & 0.80 & 2.79 & 0.00 & 0.06 & 0.09 & 0.05 & 0.33 & 0.13 & 0.05 & 0.09 & 0.01 & 0.00 & LA-ICP-AES & Unweathered \\
\hline HLB12-white1 & 0.10 & 21.46 & 0.01 & 0.05 & 0.07 & 0.08 & 0.16 & 0.07 & 0.02 & 0.03 & 0.00 & 0.00 & LA-ICP-AES & Unweathered \\
\hline HLB12-white2 & 0.20 & 28.14 & 0.01 & 0.04 & 0.06 & 0.14 & 0.30 & 0.07 & 0.02 & 0.04 & 0.00 & 0.00 & LA-ICP-AES & Unweathered \\
\hline
\end{tabular}


with the cobalt source. Moreover $0.09 \% \mathrm{CoO}$ in the 'black' component of HLB12 may contribute to the colour-but $44.77 \%$ of $\mathrm{MnO}$ clearly dominates the colour. The analysis shows that it is mainly of the pigment on the bead's surface.

Translucent blue and green glasses contain between 0.44 and $3.2 \% \mathrm{Fe}_{2} \mathrm{O}_{3}$. Four contain $\mathrm{MnO}$ levels of below $0.09 \%$ so it would have been added adventitiously. The balance contains between 0.15 and $0.29 \% \mathrm{MnO}$. It is notable that the opaque yellow and white glasses also contain quite high levels of $\mathrm{Fe}_{2} \mathrm{O}_{3}$. The yellow glasses contain relatively low $\mathrm{MnO}$, whereas opaque white glasses can contain upto $0.76 \% \mathrm{MnO}$ (excluding HLB12).

\section{Raman spectroscopy}

As shown in Fig. 2, eight out of ten glass eye beads (HLB-1 to HLB-6, HLB-8, and HLB-9) are opaque or have opaque decoration. Raman spectroscopy was used to try to identify crystalline opacifiers in the glass without damaging the beads. Tests were conducted in the Emperor Qin Shihuang's Mausoleum Site Museum only found peaks in HLB-4 and HLB-5 glass, possibly due to the weathering layers. Additional tests conducted at the Northwestern Polytechnic University gave same results. The results are shown in Figs. 3 and 4.

The results of Raman spectroscopy for the opaque yellow eyes show peaks at $134 \mathrm{~cm}^{-1}$ and $322 \mathrm{~cm}^{-1}$, similar to the peak for lead-tin yellow, a synthetic material that is widely used for making opaque yellow glass [20]. According to the crystalline structures and chemical compositions (Table 4), lead-tin yellow has two crystalline types, $\mathrm{Pb}_{2} \mathrm{SnO}_{4}$ and $\mathrm{PbSn}_{1-\mathrm{x}} \mathrm{Si}_{\mathrm{x}} \mathrm{O}_{3}$. When compared to other published results [21], the opacifier used in the yellow eyes is $\mathrm{PbSn}_{1-\mathrm{x}} \mathrm{Si}_{\mathrm{x}} \mathrm{O}_{3}$.

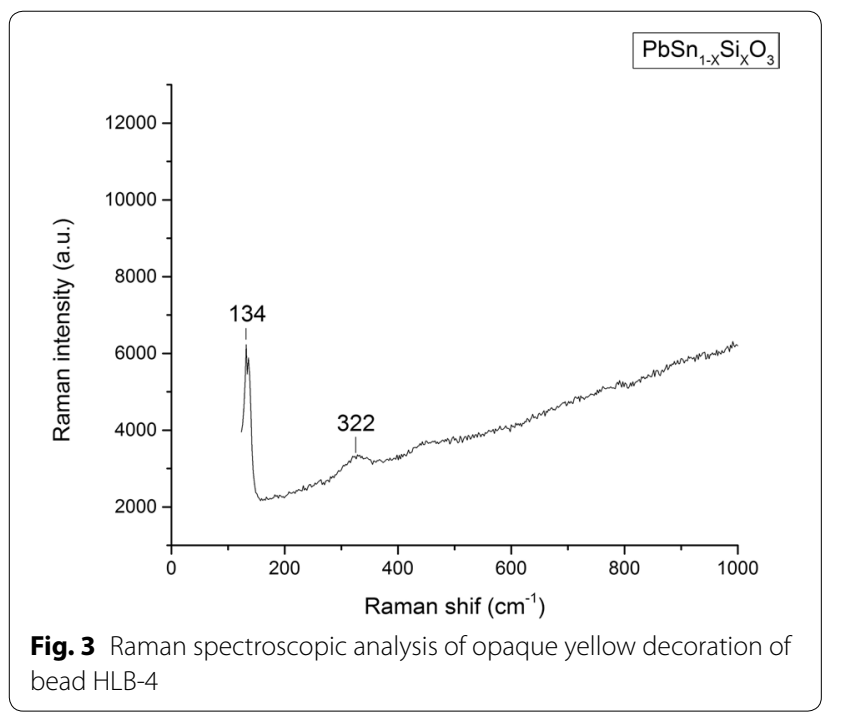

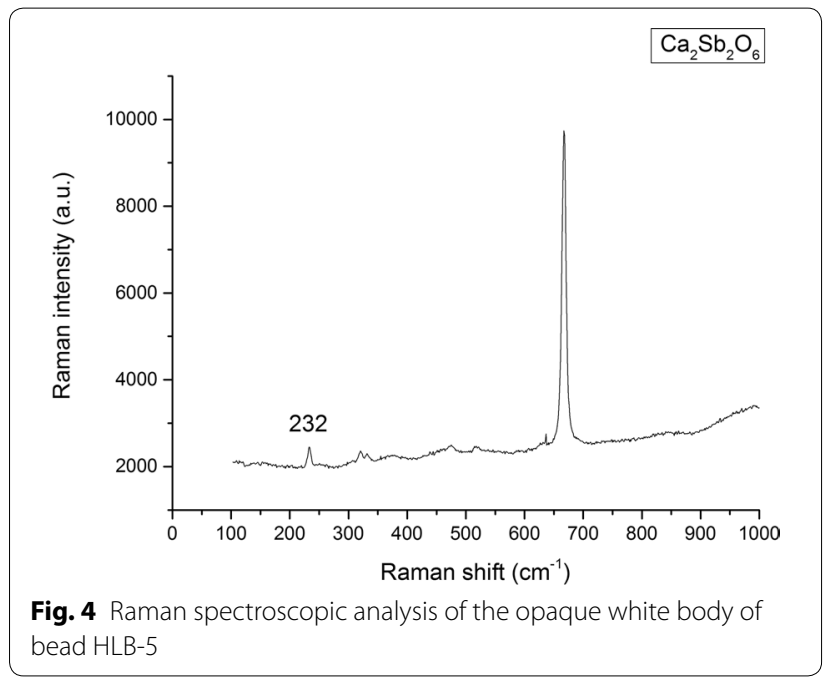

Four beads among the opaque beads (HLB-3, HLB-5, HLB-6, and HLB-9) show high contents of antimony ranging from $1.35 \%$ to $8.49 \mathrm{wt} \%$ in the white parts; all were tested using Raman spectroscopy. Only the surface was analyzed to avoid damage to the sample. Only HLB-5 shows two peaks of different intensities at $232 \mathrm{~cm}^{-1}$ and $667 \mathrm{~cm}^{-1}$, corresponding to calcium antimonate $\left(\mathrm{Ca}_{2} \mathrm{Sb}_{2} \mathrm{O}_{6}\right)$ [13]. Other samples probably contain calcium antimonite used as an opacifier producing a white glass, but Raman didn't produce results for them, probably because of weathering. Moreover, HLB12 has opaque white decoration which was found to contain high antimony. However, this also contains high $\mathrm{P}_{2} \mathrm{O}_{5}$ which will be discussed below.

\section{Microscopic observation}

Although the number of glass beads from Bizili is limited, they are rich in information about manufacturing processes. We found three special types of glass beads: eye beads, trail-decorated or possibly etched beads and beads with applied pigment decoration. Figures 5, 6, 7 show microscopic images of representative glass beads of different types. The optical microscope can reveal manufacturing traces on the surface of glass beads, while SR- $\mu \mathrm{CT}$ can reveal the internal structures.

The glass bead HLB-10 is fragmentary. The yellow decoration is probably trailed on but it is possible also that the surface was etched and the decoration inlaid. The possible evidence for etching is provided by observations under the microscope: see Fig. 6a. Figure 6b, c show the SR-Mct of the body and the decoration, respectively.

\section{Discussion}

Chemical compositions

As shown in Fig. 8, The plot of $\mathrm{MgO}$ versus $\mathrm{K}_{2} \mathrm{O}$ in the glass beads shows two distinctive main groups. One has 


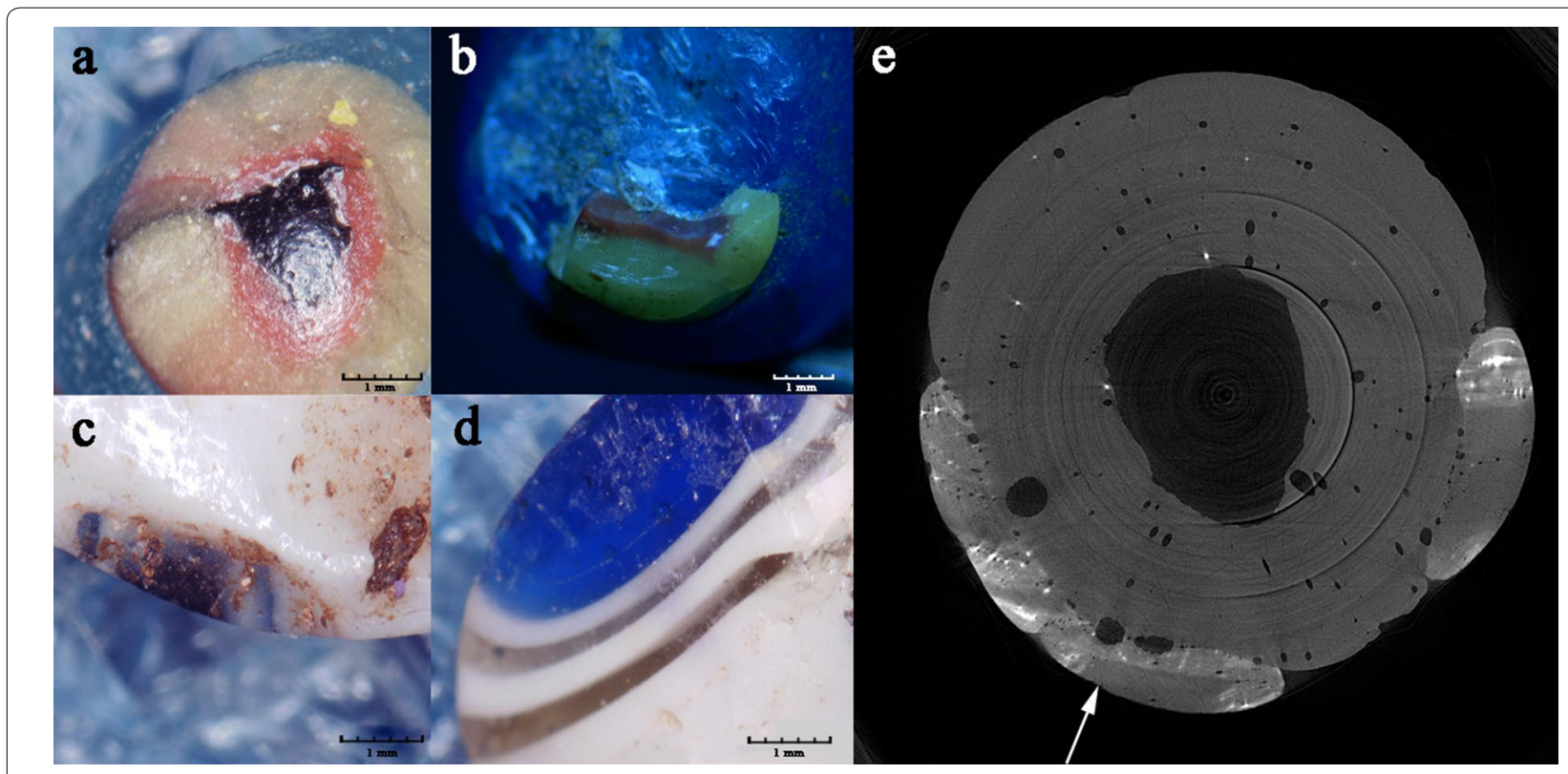

Fig. 5 Microscopic images of the glass eye beads (a HLB-1; b HLB-4; c HLB-9; $\mathbf{d}$ HLB-6; e HLB-1). a-d Show microscopic features of glass eyes in the beads. e Is the result of SR- $\mu \mathrm{CT}$ showing the bead in section. The arrow indicates a location where one of the eyes is located on the bead
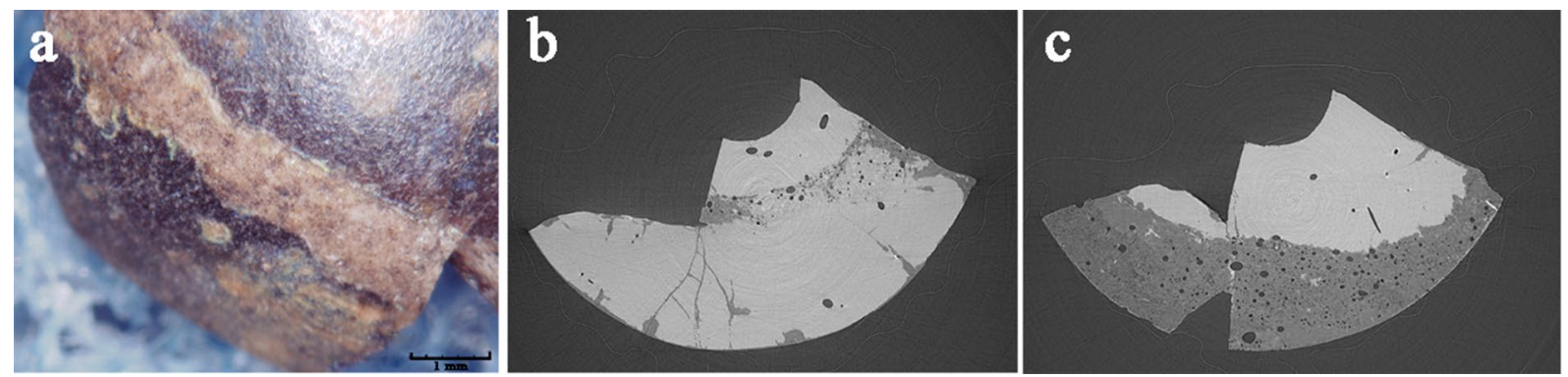

Fig. 6 Microscopic images of the glass bead with single stripe decoration (HLB-10)
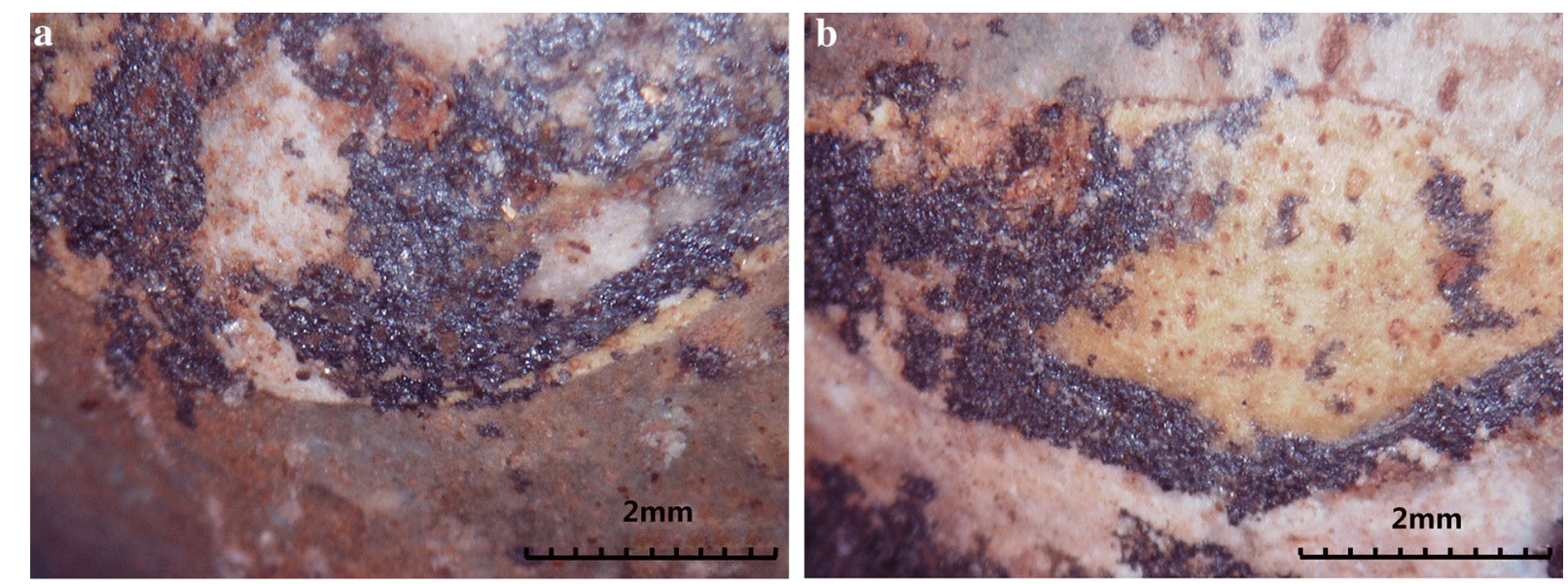

Fig. 7 Microscopic observation of glass bead HLB-12 showing opaque white decoration with black surface pigment 
low magnesia and variable potassium oxide levels of upto $3 \%$, the other contains c. $2-4 \% \mathrm{MgO}$ and $4.5-7 \% \mathrm{~K}_{2} \mathrm{O}$. The first group consists of measurements of HLB-5, HLB6, HLB-7 and HLB-9, including 2 measurements of different colours. There is a group of 3 glasses between the 2 main groups. One measurement (HLB9-black, with high $\mathrm{Al}_{2} \mathrm{O}_{3}$ (6.9\%), 0.4\% $\mathrm{MgO}$ and $\mathrm{K}_{2} \mathrm{O}(5.5 \%)$ can be considered as an outlier. In Table 1 weathered and unweathered glasses are distinguished. Lower $\mathrm{Na}_{2} \mathrm{O}$ and $\mathrm{K}_{2} \mathrm{O}$ are often associated with the alkali being leached during weathering. The $\mathrm{MgO}$ and $\mathrm{K}_{2} \mathrm{O}$ contents above $1.5 \mathrm{wt} \%$ indicate the use of a plant ash source of alkali. Those glasses with high potassium oxide and magnesia are therefore of a plant ash composition. Colorants used in the glasses are discussed above. The glasses that contain less than $1 \%$ $\mathrm{MgO}$ are nevertheless not natron glasses because they also contain elevated potassium oxide.

Natron glass is the predominant type of ancient glass in the Mediterranean and Europe from the around 1000 BC until the ninth century $\mathrm{AD}[22,23]$. However, the only 2 unweathered glasses with low magnesia levels, both opaque white glass in HBL6 and HBL9, contain higher potassium oxide levels than found in natron glasses $(2.75$ and $2.3 \%$ wt. oxide). Both contain low calcium oxide and high $\mathrm{Sb}_{2} \mathrm{O}_{3}$, because they are opacified with calcium antimonate, and $5.4 / 5.6 \% \mathrm{PbO}$. They have probably been made with a mineral source of alkali; the $\mathrm{K}_{2} \mathrm{O}$ may have entered the glass as a potassium feldspar in the sands used. Other glasses containing low $\mathrm{MgO}$ are weathered and therefore do not warrant further discussion.

The second group beads (HLB-1, HLB-2, HLB-3, HLB4, HLB-8, HLB-10, HLB-11, and HLB-12) had high total alkalies. All of them are characterized by high levels of both $\mathrm{MgO}$ and $\mathrm{K}_{2} \mathrm{O}$ (over $1.5 \mathrm{wt} \%$ ), suggesting that the

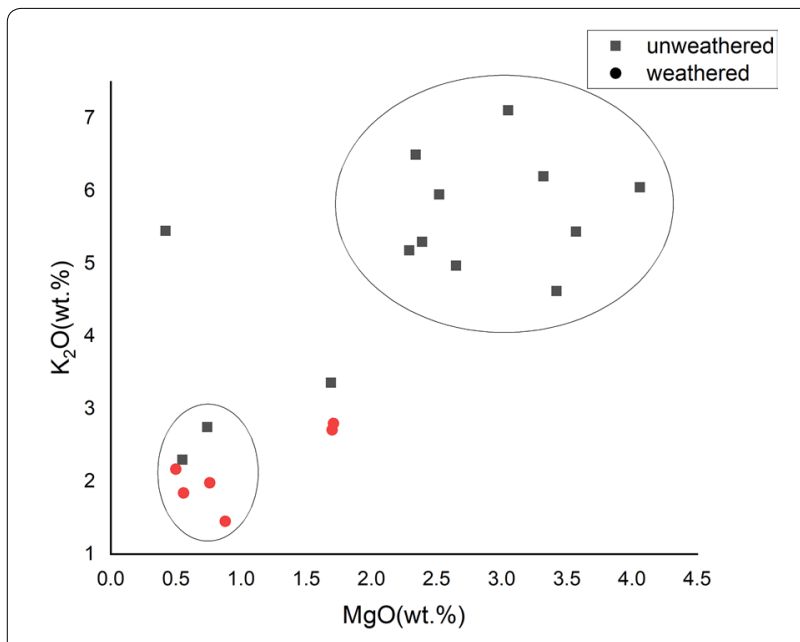

Fig. 8 Plot of $\mathrm{K}_{2} \mathrm{O} / \mathrm{MgO}$ in the samples analysed flux used was a plant ash. Plant ash can have quite variable chemical compositions according to the species of plants, the growing environment, the plant parts used, and the ashing temperatures [24]. Thus, the chemical compositions of the plant ash glass beads can vary from region to region too. The five plant ash glass beads from Bizili could derive from different regions. Five samples (HLB-1, HLB-2, HLB-4, HLB-8, and Hlb-10) are vegetal soda-lime glass ( $\mathrm{v}$-Na-Al glass) i.e. plant ash glass, with high $\mathrm{Al}_{2} \mathrm{O}_{3}$ of over $4 \%$. They have $\mathrm{MgO}$ levels of between 1.7 and $3.5 \%$ and $\mathrm{K}_{2} \mathrm{O}$ of between 2.7 and $7.1 \%$. Dussubieux [25] identified three main types of $\mathrm{v}-\mathrm{Na}-\mathrm{Al}$ glass. The first type was found in Bara [26], north-east Pakistan, a site dating from the second century $\mathrm{BC}$ to the second century AD, which was the capital of the Kushan empire, though this does not mean the glasses were fused from raw materials there. They are mainly glass ornaments found in North India, China (Xinjiang) and Bangladesh. The other two types of $\mathrm{v}-\mathrm{Na}-\mathrm{Al}$ glass were found on sites dated to c. $900 \mathrm{AD}$ and later so are not relevant to consider further here. Considering the spatial and temporal distribution of the $\mathrm{v}-\mathrm{Na}-\mathrm{Al}$ glass, our samples are closest in composition to those from Bara. The high contents of $\mathrm{Al}_{2} \mathrm{O}_{3}$ can be characteristic of central Asian glass; high alumina Indian glasses contain lower $\mathrm{CaO}$. Four of the five glass beads are similar in appearance with blue bodies and yellow centres to the eyes with red and black concentric glass around the 'pupils.' This special type of glass eye beads is found in large quantities in Bara and named as the Bara-type beads $[2,9]$. In terms of chemical compositions, the Bara beads are soda-based and characterized by relatively high $\mathrm{Al}_{2} \mathrm{O}_{3}$ and $\mathrm{CaO}$ levels varying from 4.4 to $9.4 \%$ [27]: these characteristics are similar to our samples although the blue matrix of HLB-1 has a mixed alkali composition. Collectively, the appearance, chemical compositions and distribution characteristics all suggest our glass beads may have originated from Bara. Though this does not prove that the glass used to make the beads was manufactured in Bara, it can nevertheless be suggested that the glasses used to make the beads were fused in Pakistan.

In addition to Bizili, the Bara-type glass beads have been found in many other sites in Xinjiang, including Shanpula [7], Niya [9] (shown in the Fig. 9) and Jierzankale [10]. Table 5 lists the details of the archaeological sites where Bara-type glass beads have been found in Xinjiang. Apart from Jierzankale, the other sites listed in Table 5 correspond to the date of Bara (second century $\mathrm{BC}$ to the second century $\mathrm{AD}$ ). In addition to Bara, these other sites have produced bi-color glass beads with blue matrices and with and inlaid eyes with opaque yellow circles around their 'pupils' [28]. It is possible that the Bara-type glass eye beads from Shanpula, Niya and Bizili 


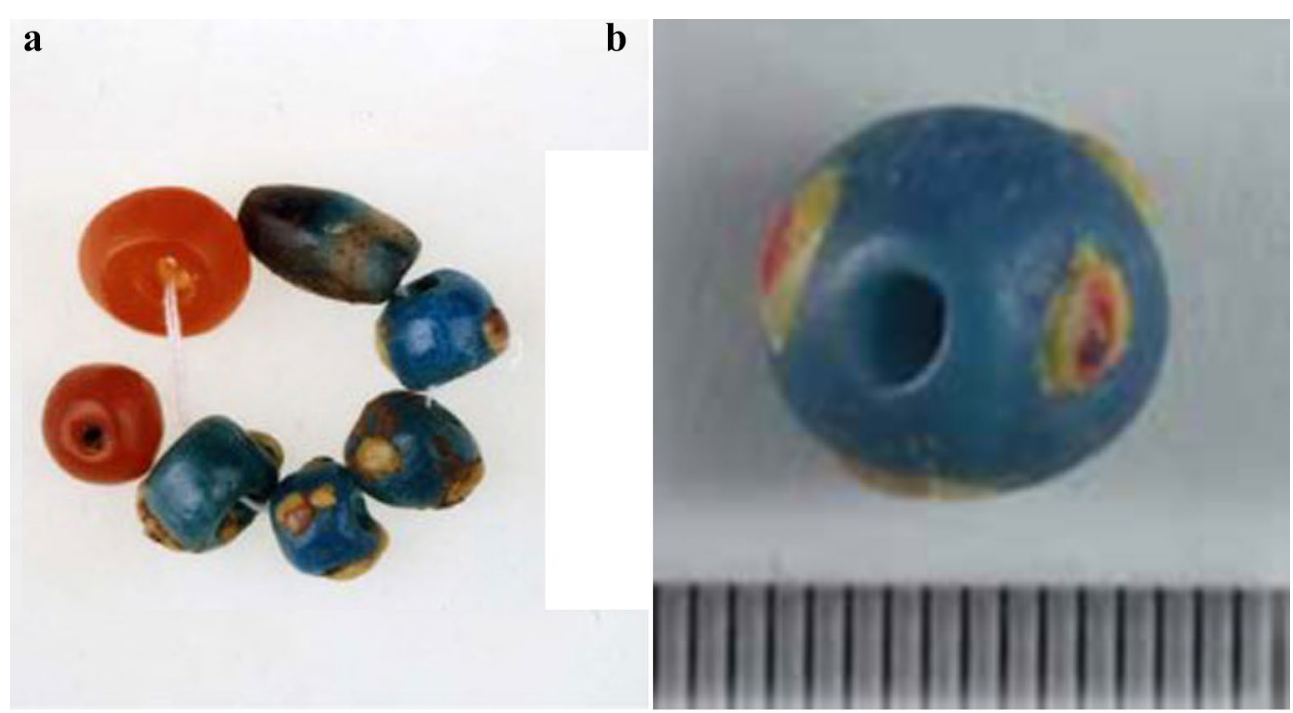

Fig. 9 Bara-type glass eye beads from other sites

Table 5 The information of the sites

\begin{tabular}{ll}
\hline Site & Age \\
\hline Jierzankale & $600-400 \mathrm{BC}$ \\
Shanpula & $100 \mathrm{BC}-400 \mathrm{AD}$ \\
Niya & $202 \mathrm{BC}-420 \mathrm{AD}$ \\
Bizili & $202 \mathrm{BC}-8 \mathrm{AD}$ \\
\hline
\end{tabular}

were made at Bara where evidence for glass working was found. However, without specific archaeological evidence for the production of these beads this must remain a tentative interpretation. The dating of Jierzankale (600$400 \mathrm{BC}$ ) is obviously earlier than that of Bara (and Bizili), showing that the glass beads found there with blue monochrome bodies decorated with multi-coloured could not have been made at Bara or other sites contemporary with Bara. It is possible that, if the eye beads from Bizili were made at Bara, their production was influenced by earlier bead making sites.

We undertook comparative studies of the published chemical compositions of contemporary glass from Mesopotamia, northern South Asia and Central Asia to investigate the possible origins of the Bizili glass beads. Some scholars consider that potash and alumina are very useful indicators in distinguishing plant ash glass from different origins [21]. With some exceptions, plant ash glass with $\mathrm{K}_{2} \mathrm{O}$ higher than $4 \%$ can suggest a central Asian origin; plant ash glass from western Asia invariably contains less than $4 \%$. From the research of Brill [15], a plot of $\mathrm{Al}_{2} \mathrm{O}_{3}$ versus $\mathrm{K}_{2} \mathrm{O}$ shows distinctive groups of glass from Mesopotamia, Northern South Asia and

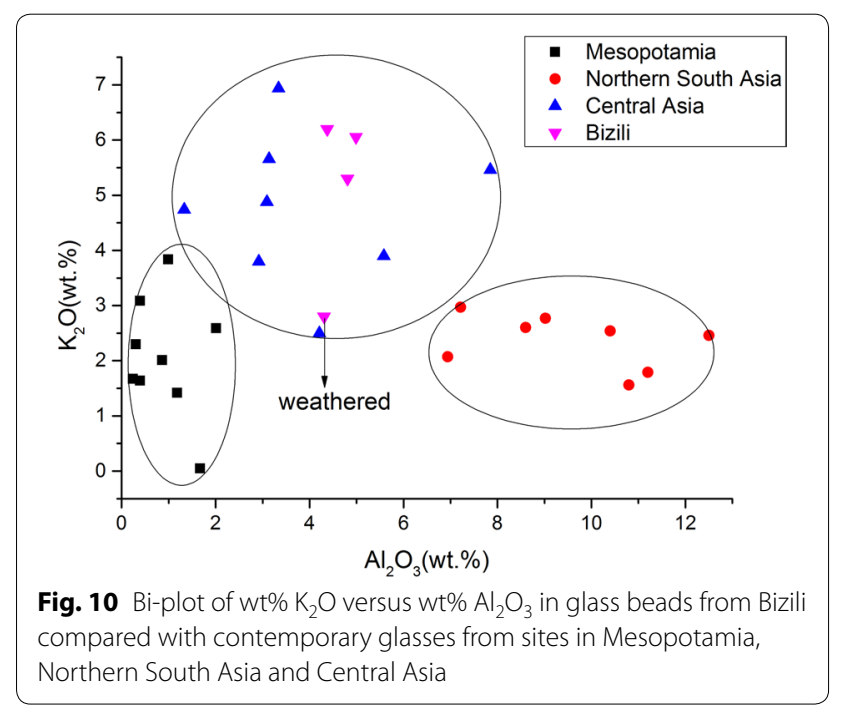

Central Asia. As shown in Fig. 10, Bizili results (for HLB3, HLB-11 and HLB-12) fall into the Central Asian area of the plot, evidence that the glass used to make them probably originated from Central Asia. Many Bizili glasses contain elevated levels of boron. The highest level detected in unweathered glass is 2000 ppm in HLB1 blue; many other unweathered glasses contain c. 1000 ppm or below. Most are the plant ash glasses, some with high alumina and two contain low magnesia and elevated potassium oxide (HLB6 white and HLB9 white). The B is likely to have entered the plant ash glasses because the plants used were growing on boron-rich evaporitic soils, as originally suggested by Brill [29]. The alkali used in the 
two examples of boron-rich glasses with low magnesium, both with $700 \mathrm{ppm} \mathrm{B}$, may have been a borate mineral deposit, with the elevated $\mathrm{K}$ being introduced by K-rich minerals in the borate deposit; though the soda levels in these glasses appear low this is partly due to the presence of c. $5.5 \% \mathrm{PbO}$ and $8.15 \mathrm{wt} \%$ and $3.4 \mathrm{wt} \% \mathrm{Sb}_{2} \mathrm{O}_{3}$ respectively in the glasses. By deleting these additives the soda level would be raised.

\section{Opacifiers}

Ancient craftsmen obtained opaque glass by adding opacifying compounds to create a dispersion of crystals or heat treating the glasses to develop opacifying crystals out of the glassy matrix. These particles included tin oxide, lead-tin oxide, calcium antimonate and lead antimonate [30]. The opaque glass beads from the Bizili site has antimony-based and tin-based opacifiers, of which the former was used far earlier than the latter in ancient glass production.

Antimony-based opacifiers were used in Late Bronze Age Egypt and Mesopotamia from the mid-second millennium $B C$ [18], in yellow lead-antimonate and white calcium antimonate. Tin based opacifiers were introduced from the second century BC and earlier [31-33], and from around the fourth century AD they tended to be the dominant opacifier used in glasses in the west [34].

The earliest lead stannate has been found in a glass bead from Sardis (the eighth to the seventh century BC) [33] and in glass beads from Poland [32].

Lead-tin oxide yellow glass became commoner in northwestern Europe at about the same time as white tin oxide glass, especially from the second century BC $[30,31]$ and was used by the Romans. During the early Islamic period (from about the eighth century AD), leadtin oxide was commonly used $[35,36]$ and this continued as late as the Mamluk caliphate (thirteenth-fourteenth centuries) for the decoration of bottles and mosque lamps, for example.

Lead-tin yellow exists as $\mathrm{Pb}_{2} \mathrm{SnO}_{4}$ or $\mathrm{PbSn}_{1-\mathrm{x}} \mathrm{Si}_{\mathrm{x}} \mathrm{O}_{3}$, both with high refractive indices $(>2)$ [37]. During the production process of lead-tin yellow glass, the lead-tin calx, the fine powder that is left after heating a mixture of lead and tin to their melting points to temperatures above $600{ }^{\circ} \mathrm{C}$ is very important. The typical opaque yellow glass has a median $\mathrm{Pb} / \mathrm{Sn}$ value of 9.1 [30]. In this study, except for HLB-4 with a $\mathrm{Pb} / \mathrm{Sn}$ value of 9.07 , the other three glass beads have relatively low $\mathrm{Pb} / \mathrm{Sn}$ values (HLB-1 = 3.79; HLB-2 = 3.70; HLB-8 = 6.60).

The occurrence of high levels of $P$ in Bizili glass beads is unusual. The blue matrix of HLB1 contains $4.16 \mathrm{wt} \%$ phosphorus pentoxide and the white decorative glass of HLB12 contains 17.18 wt $\% \mathrm{P}_{2} \mathrm{O}_{5}$. Both of these glasses contain high calcium oxide levels too at $15.99 \%$ and
$10.2 \%$ respectively. Other glasses mainly contain significantly lower levels of $\mathrm{CaO}$ so this suggests that bone ash may have been used to make the glass. Phosphorus pentoxide is invariably introduced into glasses when plant ash is used to make them [24], as is clear from our results. Tree ashes, and the glasses made from them, can contain higher levels of $\mathrm{P}_{2} \mathrm{O}_{5}[38,39]$ but had they been used it is likely that much higher levels of e.g. $\mathrm{MgO}, \mathrm{K}_{2} \mathrm{O}, \mathrm{CaO}$ and lower $\mathrm{Na}_{2} \mathrm{O}$ (c. $2 \%$ ) would have been detected in the Bizili glass beads. Therefore, a likely interpretation is that bone ash was used and that this is what has caused the very high levels of $\mathrm{P}$ and high $\mathrm{Ca}$; it is possibly present as calcium phosphate [40] but this needs to be investigated further. Nevertheless, HLB12 black contains 8.02\% $\mathrm{P}_{2} \mathrm{O}_{5}$ but much lower $\mathrm{CaO}$, so this is less easy to interpret. This is comparable to the $\mathrm{P}_{2} \mathrm{O}_{5}$ levels in black beads reported by Liu et al. [2]. The use of bone ash in these beads appears to be the first time it has been detected in ancient central Asian glasses.

The use of opacifiers was not a common feature of glass-making in Ancient China, because antimonybased opacifiers and tin-based opacifiers were not found in lead-barium glass, potassium glass or high-lead glass made in China. There are a small number of exceptions such as two bluish-green high potassium glass beads from the Kizil cemetery (500-300 BC) which contained cassiterite and c. $6 \%$ tin oxide therefore probably opacified with tin oxide $[41,42]$. First century AD white and yellow glasses from Guangxi Zhuang were also tin-opacified [43].

Thus, this supports the interpretation that the opaque glass beads from Bizili were imported. As the glass spread eastward, the use of opacifiers also gradually affected other areas. The kind of decoration used on Bara-type glass beads is likely to have been influenced by the West too.

\section{Manufacturing technology of glass beads The glass eye bead}

The Bara-type glass eye beads and other glass eye beads show obvious differences. The Bara-type glass eye beads share similar appearances and chemical compositions but are of low quality. Eyes are not bonded closely to the body of the beads and often fall out (Fig. 5b). In comparison, other glass eye beads are well-made, and have stratified glass eyes which were prevalent in the Mediterranean from the 6th to third centuries $\mathrm{BC}$, for example in Phoenician beads. Glass beads with a similar appearance dating to the fifteenth century BC have been found in Egypt [44] and also Mesopotamia later spreading to South Russia, Central Europe and other regions [45, 46]. During the East Zhou Dynasty (770-256 BC), glass production and the glass-making technique spread into 
China. Compared with glass vessels, the technique of making a glass bead is simpler, so the early glass products in China are mainly glass beads. Available archaeological records show a large number of similar glass beads have been found in southern China [47]. These glass beads are mainly lead barium glass that is uniquely made in China. The development of China's early glass industry was likely influenced by the import of stratified eye glass beads. The craftsmen learned the glass bead manufacturing techniques and imitated the appearance of stratified eye glass beads with local raw materials.

The microscopic features of glass eye beads shown in Fig. 11 indicate two ways to make eyes for insertion in beads. In Fig. 11a, it is clear that the decoration is formed by a cut section from a rod with made from different colors. The manufacturers applied stratified glass saucers which appear as concentric circles on the surface by dropping liquid glass of different colors in sequence on top of each other (Fig. 11b) as shown by the traces in the flow lines in the glass. The other method used a glass rod produced by dipping into liquid glass of different colors in sequence to produce concentric circles of glass on a rod. When solidified, the rod was cut into sections of suitable sizes which were embedded into the base beads (Fig. 11a).

The variation of brightness on a $\mathrm{CT}$ slice reflects the differences in density and chemical composition, so the base glass of the beads and eyes can be clearly distinguished by different brightnesses. In general, air bubbles in glass are of standard spherical shapes during the vitrifying process [28]. In Fig. 5e, a lot of air bubbles of different shapes are dispersed through the base glass of the bead. Between the base glass and the eyes where the bubbles accumulated, they have an oblate shape and are bigger than elsewhere. This indicates that while the base glass was in a molten state, the craftsmen inserted the pre-made eyes into the beads. Between the beads and the eyes, the air bubbles were deformed by external pressure. As shown in Fig. 5e, the arrow indicates the direction of pressure when eyes were inserted into the bead. Many small air bubbles fused to form a bigger bubble. This provides further evidence that the beads and eyes were made separately.

We drew a three-dimensional model based on the SRuCT data of sample HLB-1 as shown in Fig. 11 to show how the glass beads were made.

In general, ancient craftsmen mainly made glass beads by winding and drawing [48] normally, the bubbles in glass matrices were formed into standard spherical shapes during the vitrifying process but were deformed by winding and drawing [25]. The slender bubbles parallel to the perforation in Fig. 12b indicate that the glass bead was made by drawing. Ancient manufacturers used tools called a 'Lada', a long hollow metal pipe, in conjunction with a mobile inner rod known as the chetak [49] to draw glass into glass tubes, and then cut them into glass beads. Slender elongated bubbles are the main feature of glass beads made by drawing. Figure 12c, d are enlargement of bubbles revealing more details. The shapes of bubbles in Fig. 12d is different from others with an ellipse at one end. In the glass bead making process, the shape of bubbles is changed a lot by pulling the glass.

\section{The glass bead with single stripe decoration}

As shown in Fig. 6, though the bead HLB-10 is fragmentary, the yellow band decorations could still be observed under the microscope. Figure 6a clearly shows the position of the decoration, while Fig. $6 \mathrm{~b}, \mathrm{c}$ show many differences between the body and decoration on the SR- $\mu$ CT. In Fig. $6 \mathrm{~b}$, a dense scatter of rounded gas bubbles can be seen. The consistent brightness reflects a uniform glass phase in terms of its chemical composition. Contrasting brightnesses can be seen in Fig. 6c. The inner part of the glass bead is brighter and has few bubbles, whereas the surface of the glass bead is darker and the structure is loose and porous with a large number of bubbles. The cause for this phenomenon is likely related to the manufacturing technology

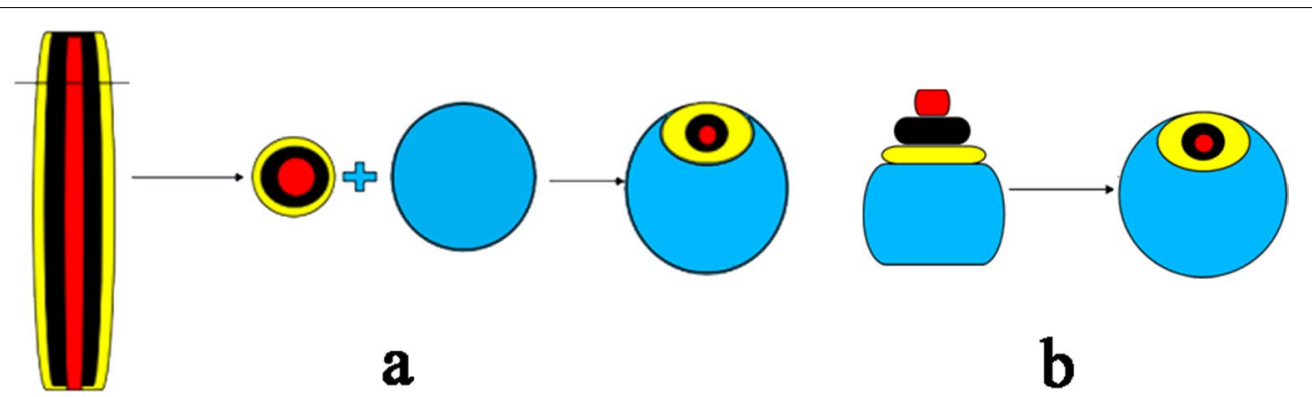

Fig. 11 The manufacturing process of stratified glass eye beads (HLB-1, HLB-2, HLB-4, HLB-8). a The method of making glass eye bead in dropping glass liquid; $\mathbf{b}$ the method of making glass eye bead in cutting off rods 


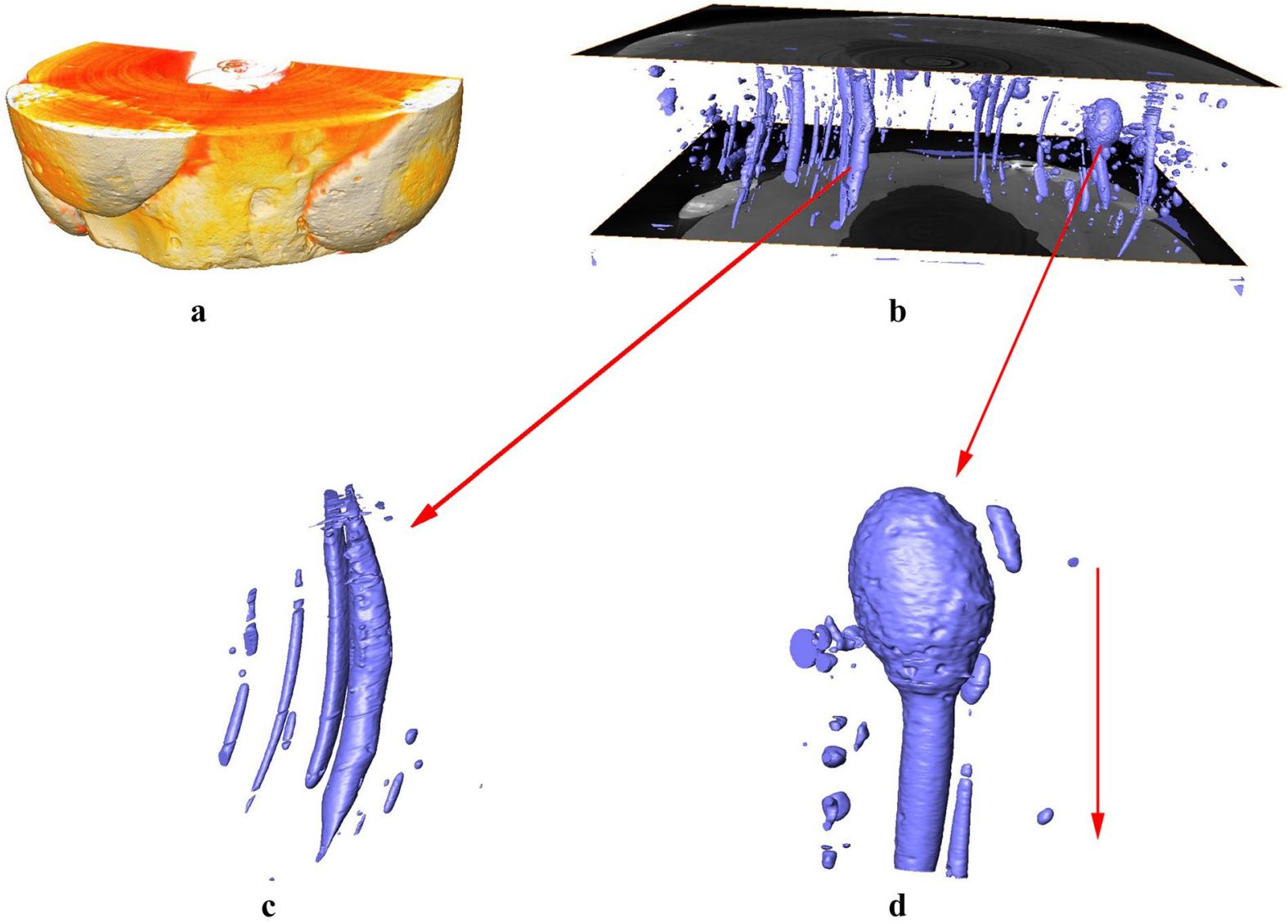

Fig. 12 a ls a three-dimensional model of sample HLB-1; $\mathbf{b}$ show themodel of bubbles in the glass bead; $\mathbf{c}$, $\mathbf{d}$ are enlarged views of typical bubbles. The arrow represents the direction of the pull

that may have been used as used for etched carnelian beads, though an alternative decorative technique is trail decorating. Early etched carnelian beads were found at the Chanhu-Daro site of the Harappa Culture in the Indus Valley at first. If etching was used the craftsmen firstly mixed a special plant juice with alkali, then etched out patterns on the body of the bead, and buried the beads in charcoal ash for permanent decoration. A large number of etched carnelian beads have been excavated in India and they display a range of decorative patterns, including a cruciform ornament [50]. By using SR- $\mu \mathrm{CT}$ we are suggesting one possible decorative technique is etching. This could explain why in the area of the decoration there are a lot of bubbles because of chemical reactions between glass and alkali. The alkali solution penetrates downward, producing a corrosion layer. Therefore we are suggesting that this is a new type of glass bead decoration influenced by the etched carnelian beads, although trail decoration cannot be excluded.

\section{The glass bead with pigment}

The glass beads with pigment (HLB-12) has a blue base with eye-like decorations. According to the results of LA-ICP-AES, the base glass is a central Asian plant ash soda-lime glass as discussed above, coloured with $0.88 \% \mathrm{CuO}$. The black pigment contains low $\mathrm{SiO}_{2}$ and high $\mathrm{MnO}_{2}(44.7 \%)$ so perhaps pyrolusite, a manganese-rich mineral, was mixed with a ground glass to produce a black pigment. The white area contains 21.4$28.1 \%$ of $\mathrm{PbO}$, but also $44 \% \mathrm{SiO}_{2}$, low total alkali, $5.38 \%$ $\mathrm{MnO}, 7.69 \% \mathrm{P}_{2} \mathrm{O}_{5}$ and $1.35 \% \mathrm{Sb}_{2} \mathrm{O}_{3}$ indicating that the material used was possibly a combination of ground glass, mineral pigments and bone ash. Optically the pigment layer appears very thin, of less than one millimeter thickness with a lot of particles. In the process of making glass beads, the craftsmen fused the monochromatic glass to make the base bead and then applied different ornamentation on the bead surface with pigments of different colors. To combine the base bead and the pigments, these glass beads were probably fired 
again. When the temperature is high, the decoration could become less regular due to the fluidity of glass.

The glass beads with pigment are rarely found in archaeological excavations except in China. Based on archaeological reports $[14,51]$, using pigments to decorate glass beads already appeared in the Central Plains area of China during the Warring States period. The chemical composition of the matrix of HLB-12 corresponds to a Central Asian origin, suggesting such decorative methods probably developed in Central Asia in the Western Han dynasty. However, given that the technology appeared earlier in China than in Central Asia, we don't exclude the possibility that Central Asia was influenced by China.

\section{Conclusion}

The occurrence of early glass in China mainly occurred near the Tianshan Mountains in Xinjiang, and was related to links with Mesopotamia and Europe. After the Western Han Dynasty, the occurrence of glass along the south of the Silk Road grew explosively, and the impact of India had become manifest [52, 53]. This study has analyzed glass beads from Bizili located on the southern part of the terrestrial Silk Road. They are mostly $\mathrm{Na}_{2} \mathrm{O}-\mathrm{CaO}-\mathrm{SiO}_{2}$, and were made with plant ash as fluxes including a smaller number of possible borate glasses. A comparative study of the chemical compositions and appearances of glass beads from other regions shows that the Bizili beads have strong foreign cultural characteristics and are believed to have originated from Central Asian and possibly from the Kushan area, including Bara in Pakistan which was a capital of the Kushan Empire.

Among the samples, there are four glass beads (blue monochrome base glasses decorated with multi-coloured eyes) which are very similar to beads from Bara. These special type of glass eye beads were found in large number in Bara, but it doesn't meant that they were created there, nor does it mean that the glasses used to make the beads were made in or near Bara. The latest archaeological evidence shows that this kind of glass bead had appeared before the Bara site, such as at Jierzankale [10]. Therefore, the Bizili beads may possibly have been made earlier than the date of Bizili and/or their production was influenced by other production in areas of central Asia, depending on how many sites specialised in making them. In addition, some opaque glass beads were opacifed with antimony-based and tin-based opacifiers. Moreover, it appears that calcium phosphate was present in the beads and may have been used as an opacifer.

In terms of glass bead making technology, there are two ways to make eyes for glass eye beads of the Bara type; the beads themselves were made by drawing. Meanwhile, 2 new types of glass bead decoration were discovered including a possible etched type and a glass bead decorated with pigments.
This research suggests that Bizili was influenced by many cultures, especially central and southern Asia. With the development of the Silk Roads, the trade and the cultural exchange between various regions became more frequent, leading to the appearance of glass objects in large quantities during the Han dynasty.

\section{Abbreviations}

$\mathrm{SR}-\mu \mathrm{CT}$ : Synchrotron radiation microtomography; ED-XRF: Energy dispersion $X$-ray fluorescence spectrometry; LA-ICP-AES: Laser ablation inductivelycoupled plasma atomic emission spectroscopy.

\section{Acknowledgements}

This study was sponsored by the National Natural Science Foundation of China (Grant No. 11575142), 111 project (D18004) and the students'innovation and entrepreneurship training program of school of cultural heritage, Northwest University (2019WYYCY-04). Special thanks go to the Shanghai Synchrotron Radiation Facility for helping with the analysis and the Xinjiang Institute of Cultural Relics and Archaeology for providing the glass beads samples in this study. Thanks to Jianfeng Cui for debugging instrument and calibration of LA-ICP-AES. Many thanks also to Xiaoya Zhan for modifying the language.

\section{Authors' contributions}

DW and RW designed the research described in this paper. All the experiment was done by DW. DW and RW drafted the majority of the manuscript. JH edited and modified the paper. XH and WL provided the samples in this study. All authors read and approved the final manuscript.

\section{Funding}

Beyond the National Natural Science Foundation of China (Grant No. 11575142) support, the 111 project (D18004) and the students' innovation and entrepreneurship training program of school of cultural heritage, Northwest University also supported this research (2019WYYCY-04).

\section{Availability of data and materials}

Please contact the corresponding author for reasonable data requests.

\section{Ethics approval and consent to participate}

This article does not contain any studies with human participants or animals performed by any of the authors.

\section{Consent for publication}

The consent for the publication of details and images in the manuscript are obtained from all participants.

\section{Competing interests}

The authors declare that they have no competing interests.

\section{Author details \\ ${ }^{1}$ Key Laboratory for Cultural Heritage Study \& Conservation (Northwest University), Ministry of Education, Xi'an 710069, PR China. ${ }^{2}$ Research Center for Archaeological Science, Northwest University, Xi'an 710069, PR China. ${ }^{3}$ Department of Classics and Archaeology, University of Nottingham, Uni- versity Park, Nottingham NG7 2RD, UK. ${ }^{4}$ Xinjiang Institute of Cultural Relics and Archaeology, Urumchi 830000, PR China.}

Received: 26 March 2020 Accepted: 25 November 2020

Published online: 08 December 2020

\section{References}

1. Chen G. Study on the cultures of the Bronze Age and early Iron Age in Xinjiang area. Archaeology. 1990;4:366-74 (In Chinese).

2. Liu S, Li QH, Gan F, Zhang P, Lankton JW. Silk Road glass in Xinjiang, China: chemical compositional analysis and interpretation using a high-resolution portable XRF spectrometer. J Archaeol Sci. 2012;39(7):2128-42. 
3. Yingzhu W. The technological research of faience in Western Zhou and Eastern Zhou periods. University of science and technology Beijing, Doctoral dissertation. 2019. p. 1-6 (In Chinese).

4. Liu N, Yang Y, Wang Y, et al. Nondestructive characterization of ancient faience beads unearthed from Ya'er cemetery in Xinjiang, Early Iron Age China. Ceram Int. 2017:43(13):10460-7.

5. Xinjiang Institute of Cultural Relics and Archaeology. Saensayi site of Xinjiang, China. Cultural Relics. 2013. p. 1-261 (In Chinese).

6. Gan F, Li Q, Gu D, et al. Study on early glass beads unearthed from Baicheng and Tacheng of Xinjiang. J Chin Ceram Soc. 2003;07:663-8.

7. Xinjiang Institute of Cultural Relics and Archaeology. Shanpula, Xinjiang, China. The Peoples Press of Xinjiang. 2001. p. 1-239 (In Chinese).

8. Yu Z. Archaeological excavation of Niya site M8 cemetery in Xinjiang. Cult Relics. 2000;2000(1):4-40 (In Chinese).

9. Lin Y. A scientific study of glass finds from the Niya site in Xinjiang, Doctoral dissertation. 2009. p. 1-171 (In Chinese)

10. Wu X. Archaeological excavation of Jierzankale Cemetery in Xinjiang in 2013. West Reg Stud. 2014;2014(1):124-7 (In Chinese)

11. Cheng Q, Guo JL, et al. Characteristicsofchemicalcompositionofglassfindsfromthe Qiemo tombsitesonthe Silk Road. Spectrosc Spectr Anal. 2012;32(7):1955-60.

12. Hu X, et al. New archaeological discovery of Bizili Cemetery in Luopu County, Xinjiang. West Reg Stud. 2017;2017(1):144-6 (In Chinese)

13. Yang J, Zhao HX, Yu P. Analysis of composite glass beads (eye-beads) unearthed from the Shahe Tomb in the Changping District of Beijing. Sci Conserv Archaeol. 2012;24(2):74-83 (In Chinese)

14. Zhao D. Exotic beads and pendants in ancient China: from western Zhou to eastern Jin Dynasty. Beijing: Science Press; 2016. p. 54-5 (In Chinese)

15. Brill R. (with a contribution by Brandt A. Rising). Chemical analyses of early glasses. Corning: The Corning Museum of Glass; 1999.

16. Panighello S, Orsega EF, Elteren JTV, et al. Analysis of polychrome Iron Age glass vessels from Mediterranean I, II and III groups by LA-ICP-MS. J Archaeol Sci. 2012;39(9):2945-55.

17. Henderson J, Warren SE. X-ray fluorescence of Iron Age glass: beads from Meare and Glastonbury Lake Villages. Archaeometry. 2010;23(1):83-94.

18. Shortland A. The used and origin of antimonate colorants in early Egyptian glass. Archaeometry. 2002;44(4):517-30.

19. Duckworth C, Henderson J, Rutten FJM, Nikita K. Opacifiers in late Bronze Age glasses: the use of ToF-SIMS to identify raw ingredients and production techniques. J Archaeol Sci. 2012;39:2143-52.

20. Cheng Q, Guo J. The use of antimony and tin in ancient western glass making. In: Tenth national symposium on archaeology and heritage conservation. 2008. p. 386-92 (In Chinese).

21. Liu S. The development of portable X-ray fluorescence analysis and its application in scientific and technological archaeology, Doctoral dissertation. 2011. p. 77-95 (In Chinese).

22. Sayre EV, Smith RV. Compositional categories of ancient glass. Science. 1961;133(3467):1824-6

23. Gallo F, Silvestri A, Molin G. Glass from the archaeological museum of Adria (North-East Italy): new insights into Early Roman production technologies. J Archaeol Sci. 2013;40(6):2589-605.

24. Barkoudah Y, Henderson J. Plant ashes from Syria and the manufacture of ancient glass: ethnographic and scientific aspects. J Glass Stud. 2006;48(1):297-321.

25. Dussubieux L, Gratuze B, Blet-Lemarquand M. Mineral soda alumina glass: occurrence and meaning. J Archaeol Sci. 2010;37(7):1646-55.

26. Dussubieux L, Gratuze B. Nature et origine des objets en verre retrouvés áBegram (Afghanistan) et á Bara (Pakistan). In: Bopearachchi O, Landes C, Sachs C, editors. De l'Indus á l'Oxus: Arché ologie de I'Asie Centrale. Lattes: Association Imago, Musée de Lattes. 2003. p. 315-23.

27. Dussubieux L, Gratuze B. Glass in South Asia. In: Janssens K, editor. modern methods of analyzing archaeological and historical glass. New York: Wiley; 2013. p. 401-30.

28. Cheng $Q$, Zhang X, Guo J, et al. Application of computed tomography in the analysis of glass beads unearthed in Shanpula cemetery (Khotan), Xinjiang Uyghur Autonomous Region. Archaeol Anthropol Sci. 2019:11:937-45.

29. Brill RH, Stapleton CP. Chemical analyses of early glasses, vol. 3, The years 2000-2011, Reports and Essays. Corning Museum of Glass, Corning, New York. 2012.

30. Matin M. Tin-based opacifiers in archaeological glass and ceramic glazes: a review and new perspectives. Archaeol Anthropol Sci. 2018;11(4):1-13.
31. Henderson J. The raw materials of early glass production. Oxf J Archaeol. 1985;4(3):267-91.

32. Purowski T, Dzierżanowski P, Bulska E, Wagner B, Nowak A. A study of glass beads from the Hallstatt C-D from southwestern Poland: implications for glass technology and provenance. Archaeometry. 2012;54:144-66.

33. Van Ham-Meert A, Dillis $S$, et al. A unique recipe for glass beads at Iron Age Sardis. J Archaeol Sci. 2019;108:0305-4403.

34. Biek L, Bayley J. Glass and other vitreous materials. World Archaeol. 1979:11:1-25.

35. Fiorentino S, Vandini M, Chinni T, Caccia M, Martini M, Galli A. Colourants and opacifiers of mosaic glass tesserae from Khirbet al-Mafjar (Jericho, Palestine): addressing technological issues by a multi-analytical approach and evaluating the potentialities of thermo-luminescence and optically stimulated luminescence dating. J Archaeol Anthropol. 2017;11:1-23.

36. Fiorentino S, Chinni T, Cirelli E, Arletti R, Conte S, Vandini M. Considering the effects of the Byzantine-Islamic transition: Umayyad glass tesserae and vessels from the qasr of Khirbet al-Mafjar (Jericho, Palestine). J Archaeol Anthropol. 2018;10:223-45.

37. Clark RJH, Cridland L, Kariuki BM, Harris KDM, Withnall R. Synthesis, structural characterization and Raman spectroscopy of the inorganic pigments lead-tin yellow types I and II and lead antimonate yellow: their identification on medieval paintings and manuscripts. J Chem Soc Dalton Trans. 1995;16:2577-82.

38. Jackson CM, Booth CA, Smedley JW. Glass by design? Raw materials, recipes and compositional data. Archaeometry. 2005;47:781-95.

39. Meek A, Henderson J, Evans J. The isotopic analysis of English Forest glass from the Weald and Staffordshire. J Anal Atomic Spectrosc. 2012;27:786-95.

40. Silvestria A, Nestola F, Peruzzo L. Multi-methodological characterisation of calcium phosphate in late-antique glass mosaic tesserae. Microchem J. 2016:124:811-8.

41. Li QI, Liu S, Zhao HX, Gan FX. Characterization of some ancient glass beads unearthed from the Kizil reservoir and Wanquan cemeteries in Xinjiang, China. Archaeometry. 2014;56:601-24.

42. Henderson J, An J, Ma H. The archaeology and archaeometry of Chinese glass: a review. Archaeometry. 2018;60:88-104.

43. Zhao HX, Li QH, Liu S, Gan FX. Characterisation of microcrystals in some ancient glass beads from China by means of confocal Raman microspectroscopy. J Raman Spectrosc. 2013;44:643-9.

44. Gan F. Development of Chinese ancient glass. Shanghai: Shanghai Scientific \& Technical Publishers; 2016. p. 69-75 (In Chinese)

45. Spaer M. Some observations on the stratified Mediterranean eye-beads of the first millennium BC. Association internationale pour l'historie du verre. Annales du 10e congres de l'association internationale pour I'histoire du verre 1985. Amsterdam: International Association for the History of Glass; 1987. p. 1-12.

46. Spaer M. Ancient glass in the Israel museum beads and other small objects. Jerusalem: The Israel Museum; 2001.

47. Yu Y. Research on beads unearthed from Hunan Province. Changsha: Hunan People's Publishing House; 2018. p. 50-253 (In Chinese).

48. Jiayao A. A brief history of glasswares in China. Beijing: Social Sciences Academic Press; 2011. p. 49-51 (In Chinese).

49. Kanungo AK. Glass beads in Indian archaeology: an ethnoarchaeological approach. Bull Deccan Coll. 2001;60-61:337-53.

50. Zhao D. Study on etched carnelian beads unearthed in China. Archaeology. 2011;10:68-78 (In Chinese).

51. Huang $X$, Yan J, Wang H. Analysis of the decorated silicate beads excavated from Tomb M4 of the Ma-Jia-Yuan Warring States Cemetery, Gansu Province. Spectrosc Spectr Anal. 2015;35(10):2895-900 (In Chinese).

52. Cheng $\mathrm{Q}$, Chun Yu, Xi L, HeW. A test and preliminary study of the composition of the glass excavated from the Norbutso Site of Ngari in Tibet-and a discussion of the Silk Road in Ngari. J Tibetol. 2017;02:264-74 (In Chinese).

53. Lv H. The study on the early burials in the western Himalaya region. Acta Archaeol Sin. 2015;2015(1):1-34 (In Chinese).

\section{Publisher's Note}

Springer Nature remains neutral with regard to jurisdictional claims in published maps and institutional affiliations. 